\title{
Palaeontology of the Middle Turonian limestones of the Nysa Kłodzka Graben (Sudetes, SW Poland): biostratigraphical and palaeogeographical implications
}

\author{
Alina Chrząstek \\ Institute of the Geological Sciences, Wrocław University, Maksa Borna 9, PL 50-204 Wrocław, Poland; \\ e-mail: alina.chrzastek@ing.uni.wroc.pl
}

\begin{abstract}
The ammonites Lewesiceras peramplum Mantell and ?Lewesiceras sp. are reported from the Upper Cretaceous in the Nysa Kłodzka Graben; they date from the Middle Turonian and ?Coniacian, respectively. The Middle Turonian limestones of the Stara Bystrzyca quarry contain an abundant assemblage of inoceramids (Inoceramus cuvieri Sowerby and I. lamarcki Parkinson) and other bivalves, including oysters, as well as brachiopods and trace fossils. Micropalaeontological data show the presence of foraminifers and siliceous sponge spiculae, bryozoans, ostracods and fragments of bivalves and gastropods. The Middle Turonian calcareous deposits belongs to the upper part of the Inoceramus lamarcki Zone (late Middle Turonian) and were deposited on a shallow, subtidal offshore shelf. They overlie the Middle Turonian Bystrzyca and Długopole Sandstones, which represent foreshore-shoreface delta deposits. The fossil assemblage suggests a moderate- to low-energy, normal-salinity environment with occasionally an oxygen deficit.
\end{abstract}

Keywords: Middle Turonian, Sudetes, Nysa Kłodzka Graben, ammonites, inoceramids, biostratigraphy

\section{Introduction}

Representatives of the ammonite genus Lewesiceras are most typical of the Middle-Late Turonian and are known from the North and Transitional European Province and from the North Pacific Province; they are rare in the Tethys Province.

Two specimens of this genus are now described from the Middle Turonian and ?Coniacian deposits in the Nysa Kłodzka Graben (Figs 1-3). One of the specimens, identified as Lewesiceras peramplum Mantell has been found for the first time in the Middle Turonian of the
Stara Bystrzyca quarry. It is, with its diameter of approx. $45 \mathrm{~cm}$, probably the biggest ammonite ever found in Nysa Kłodzka Graben and probably also in the Sudety Mountains (Fig. 6 A-E). The second specimen has been identified as ?Lewesiceras sp. - and has a diameter 33 $\mathrm{cm}$; it forms part of the collection of the Polish Geological Institute - Polish Research Institute, Wrocław (Fig. $6 \mathrm{H}-\mathrm{L}$ ). The specimen was found by Z. Radwańska, who investigated the Nysa Kłodzka Graben in (the author means: the fifties and sixties) of the $20^{\text {th }}$ century (e.g., Radwańska, 1962, 1964) in the vicinity of Wilkanów (S. Cwojdziński, PGI-PRI Wrocław, 
pers. comm. 2011) and had not yet a taxonomical assignment (Fig. 1). The ammonite was probably encountered in the Coniacian.

There is little information about large/medium ammonites (for the size categories of ammonites, see: Stevens, 1988; Matsumoto et al., 1990; Tibuleac, 2008) from the Nysa Kłodzka Graben. Only Wroński \& Cwojdziński (1984) reported some ammonites (Peroniceras tricarinatum d'Orbigny), $40 \mathrm{~cm}$ in diameter, from the Upper Turonian. It is likely that the two ammonite specimens described here (Lewesiceras

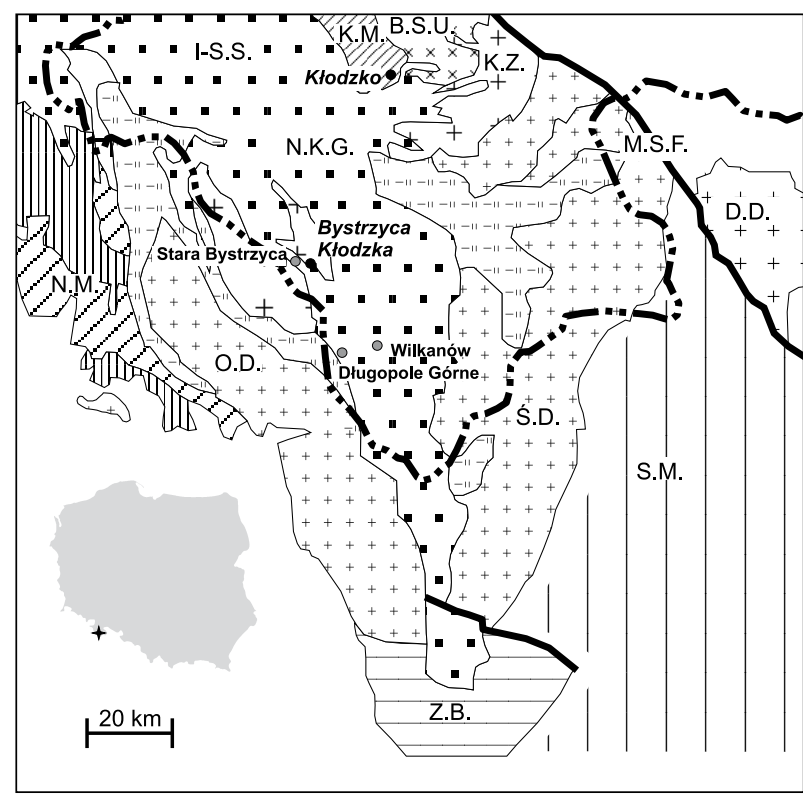

- post-orogenic cover, Upper Cretaceous

$\times \times$ late orogenic sedimentary rocks, U. Devonian-Carboniferous

Q/A metavolcanic rocks

IIIII phyllitic rocks

$-11-1$ mica schists

schists, phyllites, paragneisses, amphibolites

+ gneisses

Variscan granitoids

schists and amphibolites of the Moravo-Silesian Zone

N.K.G. Nysa Kłodzka Graben

I.-S.S. Intra-Sudetic Synclinorium

B.S.U. Bardo Structural Unit

K.M. Kłodzko Metamorphic Massif

K.Z. Kłodzko-Złoty Stok Granite Pluton

Ś. D. Śnieżnik Dome

O.D. Orlica Dome

N.M. Nove Mesto Slate-Greenstone Belt

S.M. Stare Mesto Belt

Z.B. Zabreh Belt

D.D. Desma Dome

M.S.F. Marginal Sudetic Fault

Fig. 1. Tectonic sketch of the Nysa Kłodzka Graben (after Żelaźniewicz \& Aleksandrowski, 2008). peramplum Mantell and ?Lewesiceras sp.) represent the biggest ammonites found so far in the Nysa Kłodzka Graben.

In addition to the Lewesiceras peramplum specimen, numerous moulds and shells of the inoceramids Inoceramus cuvieri Sowerby and I. lamarcki Parkinson were found in the Middle Turonian of the Stara Bystrzyca quarry (Fig. 6 M; Fig. 8 A-I). Fragments of Inoceramus cuvieri reach up to $20 \mathrm{~cm}$, while $I$. lamarcki is up to 10 $\mathrm{cm}$ and this may indicate that the dimensions of complete inoceramid shells may have diameters of $0.3-0.4 \mathrm{~m}$. One of the biggest pieces of inoceramid shell from this quarry measures 40 cm (J. Wojewoda, Wrocław University, pers. comm. 2011).

The present contribution provides a detailed description of Lewesiceras peramplum and ?Lewesiceras sp., found by the author and by Z. Radwańska. The inoceramids Inoceramus cuvieri and I. lamarcki are also described, and other fossils are depicted in this first detailed documentation of the Stara Bystrzyca quarry. Until now, only minor references concerning the lithology and fauna were made, mainly in conference materials and explanations to geological maps (Fistek \& Gierwielaniec, 1964; Radwański, 1964, 1965, 1966, 1975; Wroński \& Cwojdziński, 1984).

The fauna, especially the inoceramids, ammonites and foraminifers, were used to establish the age of the Stara Bystrzyca sandy and marly limestones, and to reconstruct the palaeogeography and palaeoenvironment.

\section{Previous research on Polish Cretaceous ammonites}

Ammonites of the genus Lewesiceras are rare in the Upper Cretaceous of the Sudety Mountains. An ammonite assigned to Pachydiscus peramplum Mantell was found by Andert (1934) in the Middle Turonian of the North Sudetic Synclinorium and in the Intra-Sudetic Synclinorium. Pachucki (1959) mentioned Pachydiscus aff. peramplum Mantell from Emscherian sediments of the Nysa Kłodzka Graben, but without any information about size and collector. Flegel (1904) reported Pachydiscus per- 


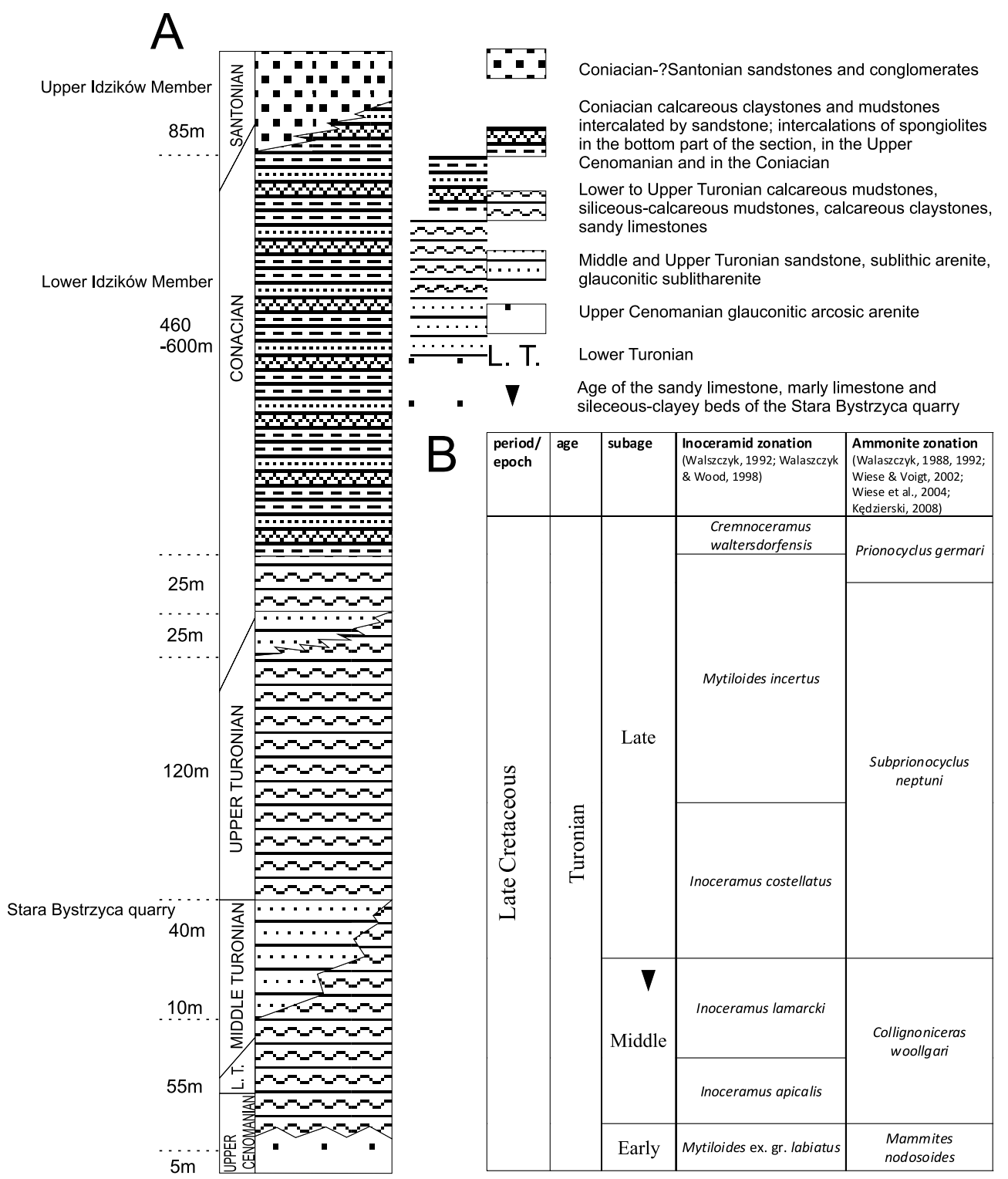

Fig. 2. Geology of the Nysa Kłodzka Graben.

A: Cenomanian-?Santonian section (slightly modified after Wojewoda, 1997, and Don \& Gotowała, 2008); B: Chronostratigraphy with inoceramid and ammonite zones (after Kędzierski, 2008, and Wiese et al., 2004).

amplum Mantell from the Upper Turonian of the Stołowe Mountains (Karłów village). In the Geological Museum in Wrocław, a specimen is present of the ammonite Pachydiscus peramplum Mantell (diameter: $16 \mathrm{~cm}$ ) from the German collection (no MGUWr. - 1800s; Fig. 6 F-G), with an inscription 'Carlsberg' (Karłów). There is, however, no information about the collector. This might be the specimen mentioned by Flegel (1904).

Recently, some researchers reported the occurrence of the Pachydiscidae species Pachydiscus (Pachydiscus) neubergicus von Hauer, Pachy- discus (P.) perfidus de Grossouvre, Pachydiscus $(P$.$) armenicus Atabekian and Akopian (Ma-$ chalski, 2012), Nowakites talavignesii d'Orbigny, Nowakites savini de Grossouvre, Nowakites pailletteanus d'Orbigny, Nowakites aff. pailletteanus d'Orbigny and Eupachydiscus isculensis Redtenbacher (Remin 2010). Jagt-Yazykova (2011; in press) analysed the evolution of mid- and Late Cretaceous ammonites (e.g. Pachydiscidae) from along the Russian Pacific coast.

Large Lewesiceras peramplum (diameter 48 $\mathrm{cm}$ ) have been described from the Middle Turonian of the Opole Trough (Tarkowski, 1991). 


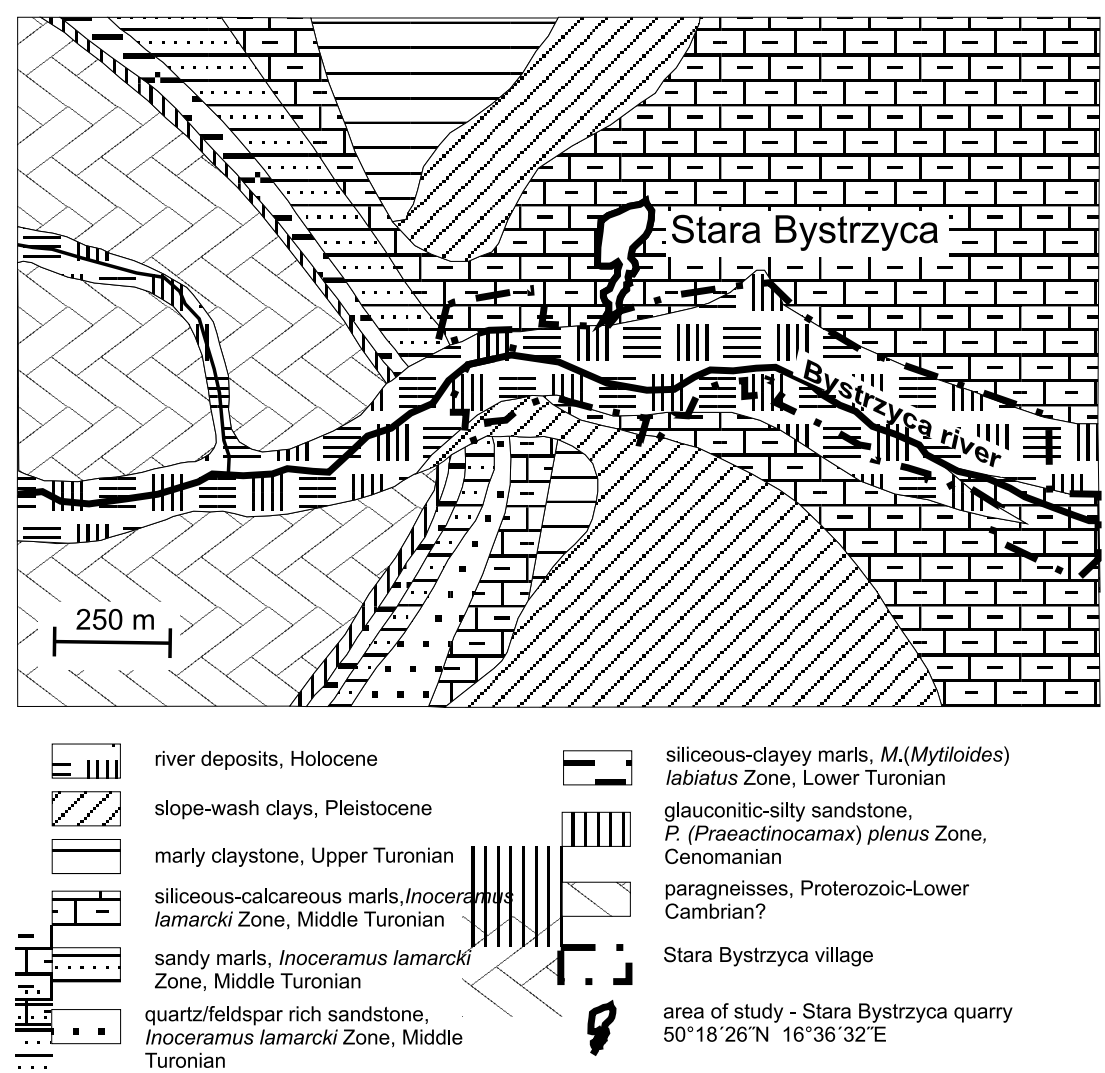

Fig. 3. Geological setting of the Stara Bystrzyca quarry (after Fistek \& Gierwielaniec, 1957). Biostratigraphy after Walaszczyk (1992).
Kin (2007) described 26 large ammonites (diameter $>50 \mathrm{~cm}$ ) assigned to Lewesiceras peramplum and L. mantelli (Opole Trough, Middle Turonian). This author suggested that all ammonites found by him might belong to one species, because the differences in morphology could be caused by different environmental conditions, for example the presence of predators (see also Trussell \& Smith, 2000). The collection of the Society of Friends of the Earth Sciences "Phacops" contains specimens of Lewesiceras peramplum (diameters $73 \mathrm{~cm}, 50 \mathrm{~cm}$ ) from the Middle Turonian of the NE Mesozoic margin of the Holy Cross Mountains (www. dinozaury.mania.pl/wp/materialy/nau-bio. pdf). Kin \& Niedźwiedzki (2012) reported some large to gigantic ammonites, including Lewesiceras peramplum (diameter $60 \mathrm{~cm}$ ) and $L$. ex. gr. peramplum (diameter $114 \mathrm{~cm}$ ), from the uppermost Middle and lower Upper Turonian of the Opole Trough. Uličný et al. (1997) found Lewesiceras sp. (diameter $70 \mathrm{~cm}$ ) in the Upper Turonian of the Bohemian Cretaceous Basin (Czech Republic).

\section{Geological setting}

The Stara Bystrzyca quarry is situated in the Nysa Kłodzka Graben (Fig. 1), which is one of the youngest tectonics units in the Sudetes (Don \& Gotowała, 2008). The graben started developing during the Turonian/Coniacian (Pachucki, 1959; Don \& Don, 1960; Komuda \& Don, 1964; Jerzykiewicz, 1970, 1971; Radwański, 1975; Don, 1996; Wojewoda, 1997; Don \& Wojewoda, 2004, 2005; Kędzierski, 2005) and it is filled with clastic deposits of Cenomanian-Santonian age, that overlay metamorphic rocks of the Orlica-Śnieżnik Dome (Żelaźniewicz \& Aleksandrowski, 2008) (Fig. 2). The thickness of the Cretaceous succession, which consists of marls, siliceous-clayey mudstones and limestones separated by the Middle and Late Turonian Quader Sandstone - (Fig. 2 A), exceeds $1200 \mathrm{~m}$ in the Nysa Kłodzka Graben (Wojewoda, 1997).

Fistek \& Gierwielaniec (1964), Radwański (1966) and Wroński \& Cwojdziński (1984) reported the presence of two units of marls in the Middle Turonian: the first unit is $10 \mathrm{~m}$ thick and the second $50 \mathrm{~m}$. The thickness of the in- 
tercalated Quader Sandstone (Bystrzyca and Długopole Sandstone) in the vicinity of Stara Bystrzyca ranges from 45 to $60 \mathrm{~m}$ (Don \& Don, 1960; Komuda \& Don, 1964; Radwański, 1965, 1975; Wroński \& Cwojdziński, 1984).

The youngest deposits in the Nysa Kłodzka Graben (sandstones and conglomerates of the Upper Idzików Member) are currently considered as being of Coniacian and Santonian age (Don \& Wojewoda, 2004; Wojewoda, 2004).

\section{The Middle Turonian of the Stara Bystrzyca quarry}

Calcareous-siliceous deposits outcrop in the Stara Bystrzyca quarry, located in the centre of the village; the quarry occurs near a fault that separates Late Cretaceous sediments from Proterozoic rocks of the Bystrzyca-Orlica Dome (Figs 1, 3). The Middle Turonian sediments of the Stara Bystrzyca quarry are represented by sandy and marly limestones with intercalations of siliceous-clayey beds (Figs 3, 4, 5). The ammonite Lewesiceras peramplum Mantell was found in the western wall (Fig. 4 B), while abundant inoceramids Inoceramus cuvieri Sowerby and I. lamarcki Parkinson occur mainly on the eastern wall (Fig. 4 A). Other bivalves (Lima canalifera Goldfuss, Lima elongata Geinitz, Lima granulata Nilsson, Pecten membranaceus Nilsson, Pecten virgatus Nilsson) and sponges prevail in the western and northern walls of the quarry. Oysters (Exogyra cornuarietis NilssonGriepenkerl, Exogyra sp.) are abundant in all walls of the quarry.

Analysis of thin sections shows that the most common matrix is calcareous and not clayey as was suggested earlier (Pachucki, 1959; Radwański, 1975). The deposits in the Stara Bystrzyca quarry thus are sandy limestones, although marly limestones occur as well (Lorenc, 1978; Manecki \& Muszyński, 2008). Apart from that, $0.05-\mathrm{mm}$ grains occur (at the boundary between sand and silt); they consist mostly of quartz and rare feldspars, muscovite and opaque minerals (Fe-oxides or coalified organic matter). Bioclasts (siliceous sponge spiculae, fragments of bivalve and gastropod shells, ostracods and bryozoans) are quite common.
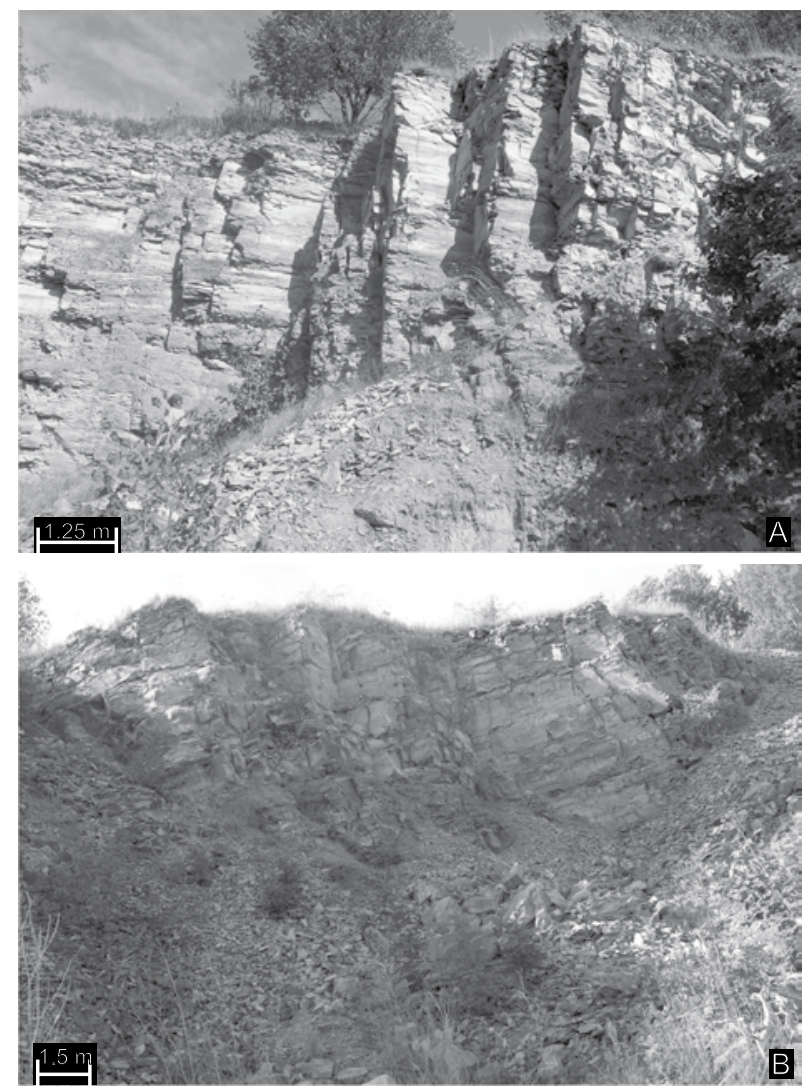

Fig. 4. The Stara Bystrzyca quarry.

A: The north-eastern wall which contains abundant inoceramids; B: The western wall where the specimen of Lewesiceras peramplum Mantell was found.

\section{Systematic descriptions of the fossils}

The literature used to determine the fossils included works by Scupin (1912-1913), Andert (1934), Moore (1968), Kennedy \& Wright (1981), Malinowska (1984), Walaszczyk (1988, 1992), Tarkowski (1991) and Kaesler (1996). Foraminifers observed in thin sections were determined on the basis of works by Witwicka (1958), Moore (1964), Jerzykiewicz \& Teisseyre (1974), Teisseyre $(1975,1992)$, Gawor-Biedowa (1980), Walaszczyk et al. (2004a) and Kędzierski et al. (2012).

All specimens are stored in the collection of the Geological Museum, University of Wrocław (catalogue numbers from MGUWr-5453s to MGUWr-5484s and MGUWr-5487s). 


\subsection{Ammonoidea}

Order Ammonoidea Zittel, 1884

Suborder Ammonitina Hyatt, 1889

Superfamily Desmoceratoidea Zittel, 1895

Family Pachydiscidae Spath, 1922

Genus Lewesiceras Spath, 1939

Synonyms

Ammonites peramplus Mantell, 1822

Lewesiceras peramplus Young, 1979

Lewesiceras peramplum Wright and Kennedy, 1984

\subsubsection{Lewesiceras peramplum Mantell, 1822}

(Fig. 6 A-E)

1840. Ammonites lewesiensis Mantell; H.B. Geinitz, p. 39

1842. Ammonites peramplus Mantell; H.B. Geinitz, p. 67, pl. 12, fig. 2; pl. 13, fig. 4

1904. Pachydiscus peramplus Mantell; K. Flegel, p. 21

1934. Pachydiscus peramplus Mantell; H. Andert, pp. 397-398

1972. Lewesiceras peramplum Mantell; R. Marcinowski and M. Szulczewski, pp. 532-535, pl.

4, figs $1-2$

1981. Lewesiceras preramplum Mantell; W.J.

Kennedy and C.W. Wright, pp. 495-500, pl.

74, figs 1-2; 75, figs 1-7; text-figs 1, 2A-B

1988. Lewesiceras peramplum Mantell; I.

Walaszczyk, pl. 4, fig. 3

1991. Lewesiceras peramplum Mantell: R.

Tarkowski, pp. 125-126, pl. 21, fig. 3; pl. 22,

fig. 4

For a comprehensive synonymy, see Kennedy \& Wright (1981), Kennedy et al. (1983), Walaszczyk (1988), and Tarkowski (1991).

Material

A single specimen, stored at Geological Museum, University of Wrocław, No MGUWr5453s, preserved as an internal mould.

\section{Specimen's description}

The specimen from the Stara Bystrzyca quarry is an internal mould with a diameter of approx. $45 \mathrm{~cm}$. As some part of a whorl is missing on the ventral side, the initial diameter of this ammonite might have been larger $(? 49 \mathrm{~cm})$. The large diameter of the ammonite is typical of the genus Lewesiceras. Because the suture line is invisible, it is difficult to state if the phragmocone is complete and if the body chamber is present. The suture line has been presented by, among others, Kennedy et al. (1983) and Kennedy \& Wright (1981).

The specimen has ornamentation in the form of tubercles that stretch into primary ribs. The umbilicus is covered with a rock fragment but it seems to be narrow, because the tubercles are party visible. On the side of the whorl, at the umbilical margin, eight tubercles of various sizes and eight primary ribs are visible. The largest tubercle is $3 \mathrm{~cm}$ wide; the following ones are less distinct. The tubercles pass forwards into lengthwise, straight or slightly curved primary ribs that are poorly marked. Every primary rib is followed by a depression. Smaller secondaries (intercalaries) are not visible. The ventral side is rounded, narrower and smooth. The whorls' height $(19.0 \mathrm{~cm})$ is always larger than the whorls' width $(13 \mathrm{~cm})$ (see the morphological features of the ammonite shell in Fig. 7). The ornamentation of the early and median portions of the phragmocone (inner whorls) is more expressed than on the external whorls.

In general, the ornamentation gradually disappears, which is a characteristic feature of this species. Adult specimens of Lewesiceras peramplum have a sculpture consisting of wide, flat ribs that are developed close to the umbilicus only; occasionally the last whorl is completely devoid of sculptures.

\section{Discussion}

Lewesiceras belongs to Pachydiscidae. Eopachydiscus Wright 1955 was confirmed as the earliest (Upper Albian) representative of the Pachydiscidae. Matsumoto (2003) described a new ammonite species, Lewesiceras shimanukii from the Lower Coniacian of Japan and regarded it as transitional between Eopachydiscus and the common species of the genus Lewesiceras well known for their enormous size.

\section{Occurrence}

The genus Lewesiceras is known from the North European Province of the Boreal Realm and from the Northern Transitional Subprovince (Poland, the Czech Republic, Germany, France, Great Britain, Spain, Romania, Bulgaria, $\mathrm{S}$ Sweden), but it has also been reported from other regions such as the Pacific Province 
Fig. 5. Section of the Middle Turonian in the Stara Bystrzyca quarry.

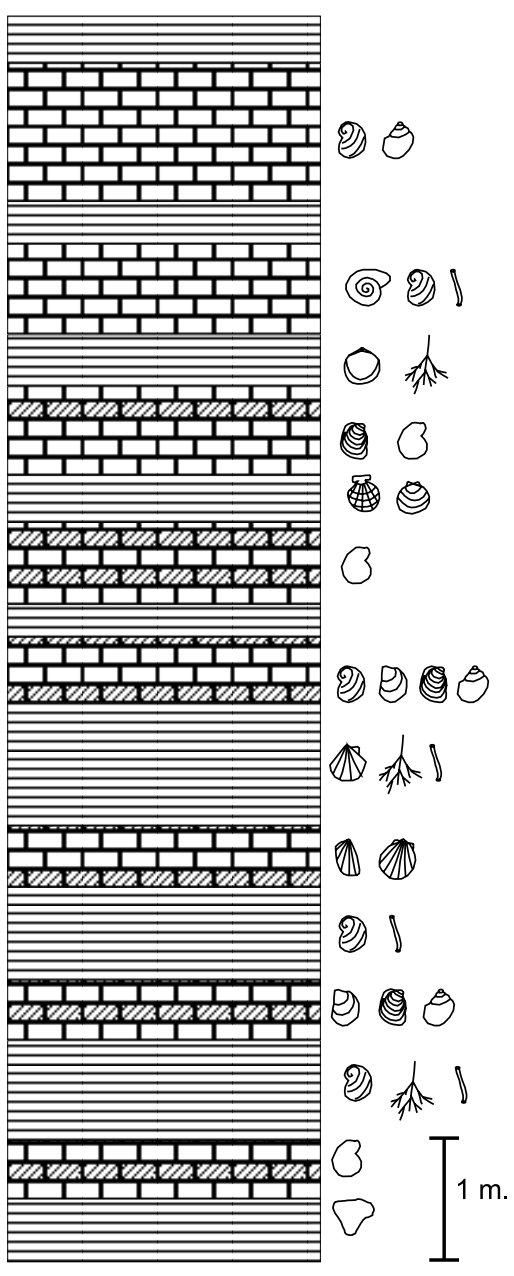

or Tethys Province (Japan, Montana (USA), Madagascar, North Africa, S India, Russia) and Asia (Crimea, Causasus, Kazakhstan) (Moore, 1968; Kennedy \& Wright, 1979; Matsumoto, 1979; Kennedy \& Wright, 1981, Čech, 1989; Lamolda et al., 1989, Tarkowski, 1991; Kaesler, 1996; Marcinowski et al., 1996; Wiese \& Kaplan, 2001; Ion et al., 2004; Košt'ák et al., 2004; Wiese et al., 2004; Ekrt et al., 2008). The genus Lewesiceras is known from SE France and this confirms migration of this boreal ammonite, during a cooling phase in the late Middle Turonian, in a southern direction (Wiese \& Voigt, 2002; Košt'ák \& Wiese, 2011). It is found from the Upper Cenomanian to the Coniacian in $\mathrm{Eu}$ rope, especially in deposits from the Early to the end of the Middle Turonian (Kennedy \& Wright, 1981). According to Kaesler (1996), the genus Lewesiceras occurs from the Early Cenomanian to the ?Coniacian of Europe.

From the Lower Turonian, Lewesiceras peramplum is known from NW Europe (Monnet \&
Bücher, 2007); it was found also in the Czech Republic (Tarkowski, 1991; Uličný et al., 1997; Trbušek, 1999), Great Britain, France and Spain (Kennedy \& Wright, 1981, Lamolda et al., 1989, Tarkowski, 1991, Woods, 2007), Germany (Andert, 1934) and Bulgaria (Tarkowski, 1991).

From the Middle Turonian, the species was reported from the Opole region (SW Poland) (Walaszczyk, 1988, Tarkowski, 1991, Kin, 2007), the Sudety Mountains (North Sudetic Basin and Intra-Sudetic Basin) (Andert, 1934) and the Bohemian Cretaceous Basin (Czech Republic), Germany, France and England. Seibertz (1978) and Diedrich \& Hirayama (2003) reported L. peramplum from Germany. It also was found in France and England (Kennedy \& Wright, 1979; Tarkowski, 1991; Diedrich \& Hirayama, 2003; Woods, 2007). Kennedy \& Wright (1981) stated that Lewesiceras peramplum is one of the most common ammonites in the Turonian of France, ranging from the Early Turonian to the top of the Middle Turonian (Mammites nodosoides 
- Collignoniceras woollgari Zones). Tarkowski (1991) mentioned Bulgaria and the Czech Republic, whereas Kaplan and Kennedy (1996) reported its Middle Turonian occurrence from Germany.

From the Upper Turonian, the genus was reported by Flegel (1904) from the Intra-Sudetic Basin (Stołowe Mountains). Marcinowski \& Szulczewski (1972) described L. peramplum from the Mesozoic margin of the Holy Cross Mountains, the Krakow Upland, the Polish Jura Chain-Miechów Synclinorium, the Opole Trough, the northern Caucasus and the Crimea. Tarkowski (1991), Walaszczyk (1988) and Kin (2007) reported this taxon from the Upper Turonian of Poland (Opole Trough, Miechów Synclinorium).

Marcinowski \& Szulczewski (1972), Gale (1996), Lomerzheim (1976) and Kennedy et al. (2005b) mentioned this genus from the whole Turonian of Great Britain, France, Germany, the Czech Republic and USA (Colorado).

\subsection{2. ?Lewesiceras sp.}

(Fig. $6 \mathrm{H}-\mathrm{L}$ )

\section{Material}

A single specimen, housed at the collection of the Polish Geological Institute - Polish Research Institute, Wrocław, preserved as an evolute, internal mould.

\section{Specimen's description}

An ammonite with a large, evolute shell (an internal mould). The maximum diameter of the complete shell is about $33 \mathrm{~cm}$. The coiling is evolute with an umbilical diameter of about $12 \mathrm{~cm}$. It seems that the phragmocone is rather complete, and probably the body chamber is partially or complete preserved, but this cannot be ascertained because the suture line is invisible. The ornamentation consists of dense, more or less regular ribs on the phragmocone, starting from the umbilicus. Strong, primary ribs arise from well developed elongated umbilical bullae, and are more or less regular.

The ornamentation is more developed on the inner whorls than on the external ones. The last whorl is rather smooth. The umbilicus is shallow with low, narrow, rounded umbilical shoulders. The ventral side is narrow. The whorl section tends to be compressed and flat-sided. The ornamentation changes on the outer whorls. It consists of about 20 main ribs (sinusoidal) and tubercles-bullae $(0.5-1.5 \mathrm{~cm})$. The distance between the ribs ranges from 3.0 to $5.0 \mathrm{~cm}$. The whorl's breadth is $8.0 \mathrm{~cm}$ and its height is $13 \mathrm{~cm}$ (see the morphological features of the ammonite shell in Fig. 7). All ribs end in marginal tubercles at the ventral side of the shell. On the inner and middle flank, the tubercles are straight and strong, but then bend forwards to become concave on the outer flanks. With regard to the density and shape of the ribbing, the shallow umbilicus and the evolute coiling, the specimen corresponds best to the diagnosis of ?Lewesiceras sp. The specimen differs slightly in ornamentation from $L$. peramplum and L. mantelli.

According to W.J. Kennedy (Oxford University, pers. comm. 2012), this specimen cannot be ascribed to Lewesiceras mantelli or L. peramplum because these species have 13-14 primary ribs per whorl. The specimen described has $50 \%$ more ribs. The study material is somewhat similar to Puzosia (Mesopuzosia) sp., but it differs in density and character of the ribs (Moore, 1968; Kaesler, 1996). Mesopuzosia has numerous dense and fine ribs, most of which are long, with some shorter ones in between (see Matsumoto et al., 1990). According to W.J. Kennedy (Oxford University, pers. comm. 2012), the specimen does, however, not resemble $P$. (Mesopuzosia) sp. either, because the ribs are too strong. The material corresponds well to the genus Lewesiceras sp., but due to the lack of species-level distinguishing features, identification at species level is impossible, and even the genus is questionable.

Occurrence

The genus Lewesiceras is known from the Lower Cenomanian to the ?Coniacian (Kaesler 1996). According to Kennedy \& Wright (1981), it ranges from the Upper Cenomanian to the Coniacian, and is especially common in the Lower and Middle Turonian. Ammonites described as Lewesiceras sp. have been reported from Poland (Niedźwiedzki \& Kalina, 2003) and from Czech Republic (Wiese et al., 2004). The genus Lewesiceras was also described from the Turonian of Poland (Marcinowski \& Szulczewski, 1972; Walaszczyk, 1988; Tarkowski, 

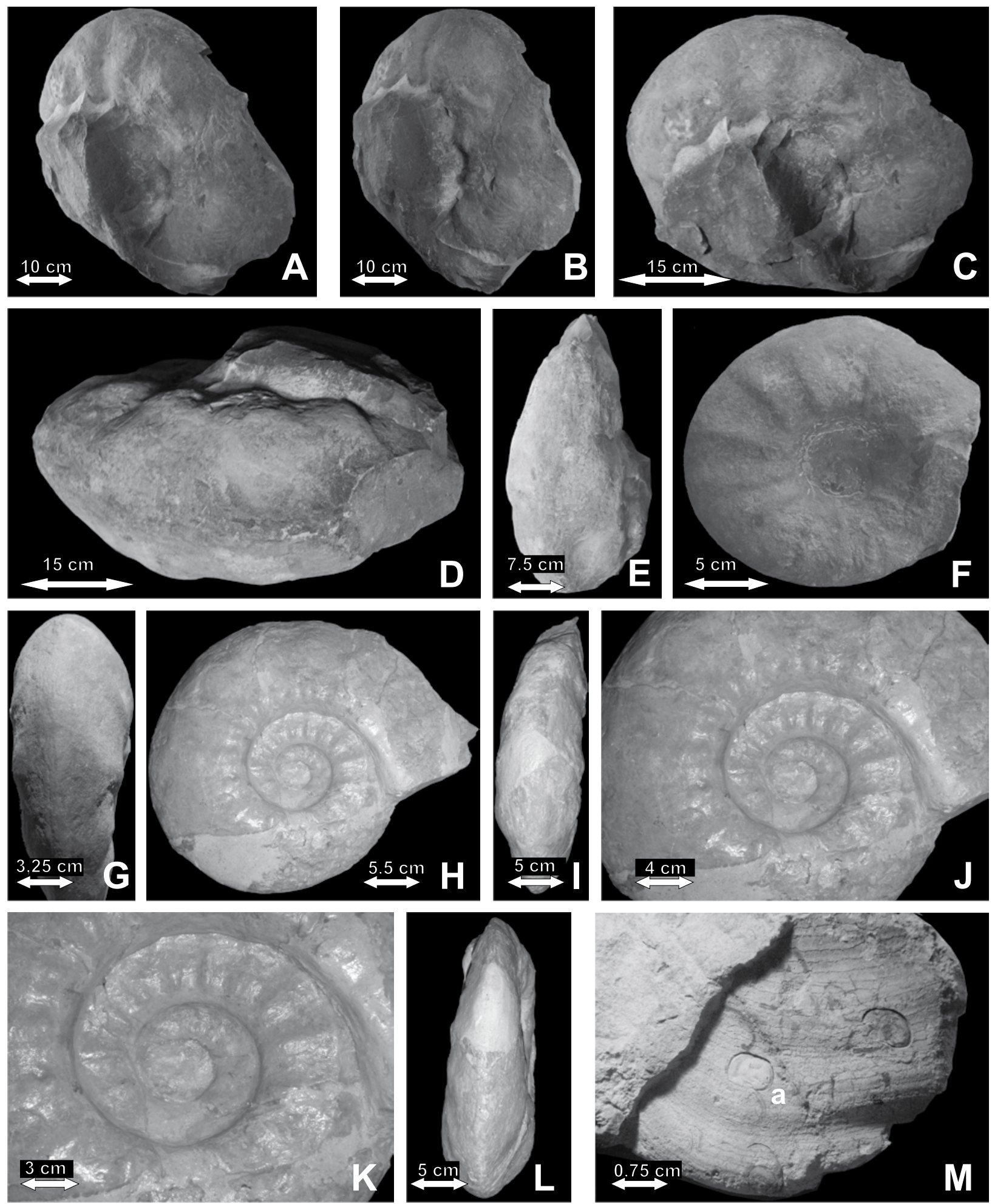

Fig. 6. Late Cretaceous ammonites and inoceramids from the Nysa Kłodzka Graben.

A-E: Lewesiceras peramplum Mantell (MGU.Wr - 5453s), Middle Turonian, Stara Bystrzyca quarry; F-G: Pachydiscus peramplum Mantell from the German collection (?Flegel 1904; no MGUWr.-1800s); H-L: ?Lewesiceras sp. from the collection of the Polish Geological Institute - Polish Research Institute, Wrocław (specimens found by Radwańska in the middle of the $20^{\text {th }}$ century), taxonomic assignment by the present author. ?Coniacian, Wilkanów (S. Cwojdziński, PGI-PRI Wrocław, pers. comm. 2011); M: Inoceramus cuvieri Sowerby, Middle Turonian, Stara Bystrzyca quarry (MGUWR-5454s); a) gastropods prints. 

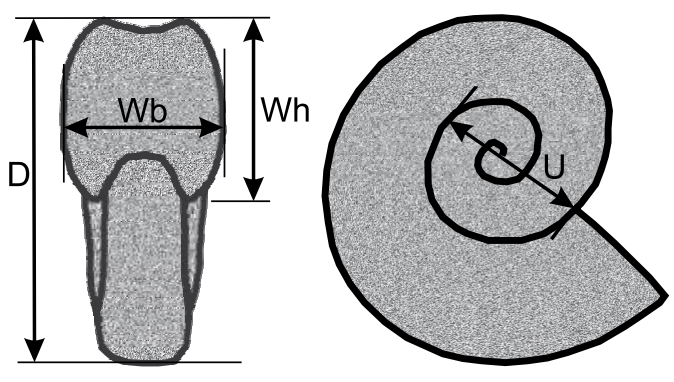

$U$ umbilucus

D diameter

Wh whorl height

$\mathrm{Wb}$ whorl breadth

\begin{tabular}{|l|c|c|c|c|r|}
\hline specimens & D & Wb & Wh & U & wb/wh \\
\hline Lewesiceras peramplum MGUWR- 5453s & $490 \mathrm{~mm}$ & $130 \mathrm{~mm}$ & $190 \mathrm{~mm}$ & - & $70 \%$ \\
\hline ?. Lewesiceras sp. (coll. PGl- PRI) & $330 \mathrm{~mm}$ & $80 \mathrm{~mm}$ & $130 \mathrm{~mm}$ & $120 \mathrm{~mm}$ & $60 \%$ \\
\hline
\end{tabular}

Fig. 7. Morphological features of an ammonite shell according to Yacobucci (2004), slightly changed. The table shows the values of these features for the specimens of Lewesiceras peramplum and ?Lewesiceras sp. under investigation.
1991; Kin, 2007; Kin \& Niedźwiedzki, 2012) and is also known from the Czech Republic (Čech 1989; Uličný et al., 1997; Trbušek 1999, Wiese et al., 2004; Ekrt et al., 2008) and Germany (Seibertz, 1978; Wiedman, 1989; Kaplan \& Kennedy, 1996; Lommerzheim, 1976; Diedrich \& Hiraya$\mathrm{ma}, 2003)$. From elsewhere in Europe it was reported from France, England, Spain, Sweden, Bulgaria and Romania (Sornay, 1964; Kennedy \& Wright, 1979, 1981; Mortimore \& Pommerol, 1991; Tarkowski 1991; Gale, 1996; Ion et al., 2004; Košt'ák et al., 2004; Woods, 2007). Outside Europe, the genus has been reported from Japan, Montana (USA), Madagascar, northern Africa, S India, Russia, the Crimea, the Causasus and Kazakhstan (Ivannikov, 1967; Collignion, 1971-1972; Matsumoto, 1979; Kaesler, 1996; Marcinowski et al., 1996; Kennedy et al., 2005a; Ayyasami, 2006; Feldman et al., 2007).

\subsection{Inoceramidae}

Family Inoceramidae Zittel, 1881

Genus Inoceramus Sowerby, 1814

\subsubsection{Inoceramus cuvieri Sowerby, 1822}

(Fig. 6 M; Fig. 8 A-C)

1901. Inoceramus cuvieri Sowerby; F. Stürm, p. 92, pl. 10, fig. 1

1957. Inoceramus cuvieri Sowerby; F. Mitura, p. 275 , pl. 27, figs $4,9,10$

1984. Inoceramus cuvieri Sowerby: L. Malinowska, pp. 362-363, pl. 156, fig. 2

1991. Inoceramus cuvieri Sowerby; R. Tarkowski, p. 106, pl. 9 fig. 13; pl. 10, fig. 5

1992. Inoceramus cuvieri Sowerby; I. Walaszczyk, p. 31, pl. 11, figs 2-3
1999. Inoceramus cuvieri Sowerby; H. Summesberger et al., p. 47, pl. 4, figs 1-2

For a comprehensive synonymy, see Mitura (1957) and Tarkowski (1991).

\section{Material}

9 specimens, No MGUWr-5454s to MGUWr-5457s, stored at the Geological Museum of Wrocław University. The fragments of large and medium-sized specimens are preserved in the form of internal moulds, in places containing shell fragments.

\section{Specimens' descriptions}

The specimens have flat, slightly convex, thick shells. The biggest specimens are only slightly convex. The outlines of the shells are subtriangular to subquadrate. The fragments are up to $15-18 \mathrm{~cm}$ long (Fig. $8 \mathrm{~A}$ ). The length of the best preserved mould (Fig. $6 \mathrm{M}$ ) is 6.0 $\mathrm{cm}$, its height is $6.5 \mathrm{~cm}$, its axial length is 6.0 $\mathrm{cm}$ and its secondary axis is $7.0 \mathrm{~cm}$ (see the morphological features of the inoceramid shell in Fig. 9). The surfaces of the internal moulds are smooth or slightly undulated with dense, regular, "jagged" growth lines that are typical of this species (Mitura, 1957). These lines are more or less regularly distributed (from 1.0 to $4.0 \mathrm{~mm}$, in most cases approx. $2.0-2.5 \mathrm{~mm}$ ). The growth rings (rugae) are wide (from 0.6 to over $1.0 \mathrm{~cm}$, max. $2.0-2.5 \mathrm{~cm}$ ), flat and bear concentric arcs. Traces of the growth lines are visible only partly; they are parallel to the rugae.

The specimens do not differ from the specimens described by Mitura (1957) and Tarkowski (1991). The shape, appearance and ornamentation - which forms a pattern of delicate "jagged" dense growth lines (Fig. $6 \mathrm{M}$; Fig. $8 \mathrm{C}$ ) - suggest that these specimens belong to the species I. cuvieri. 

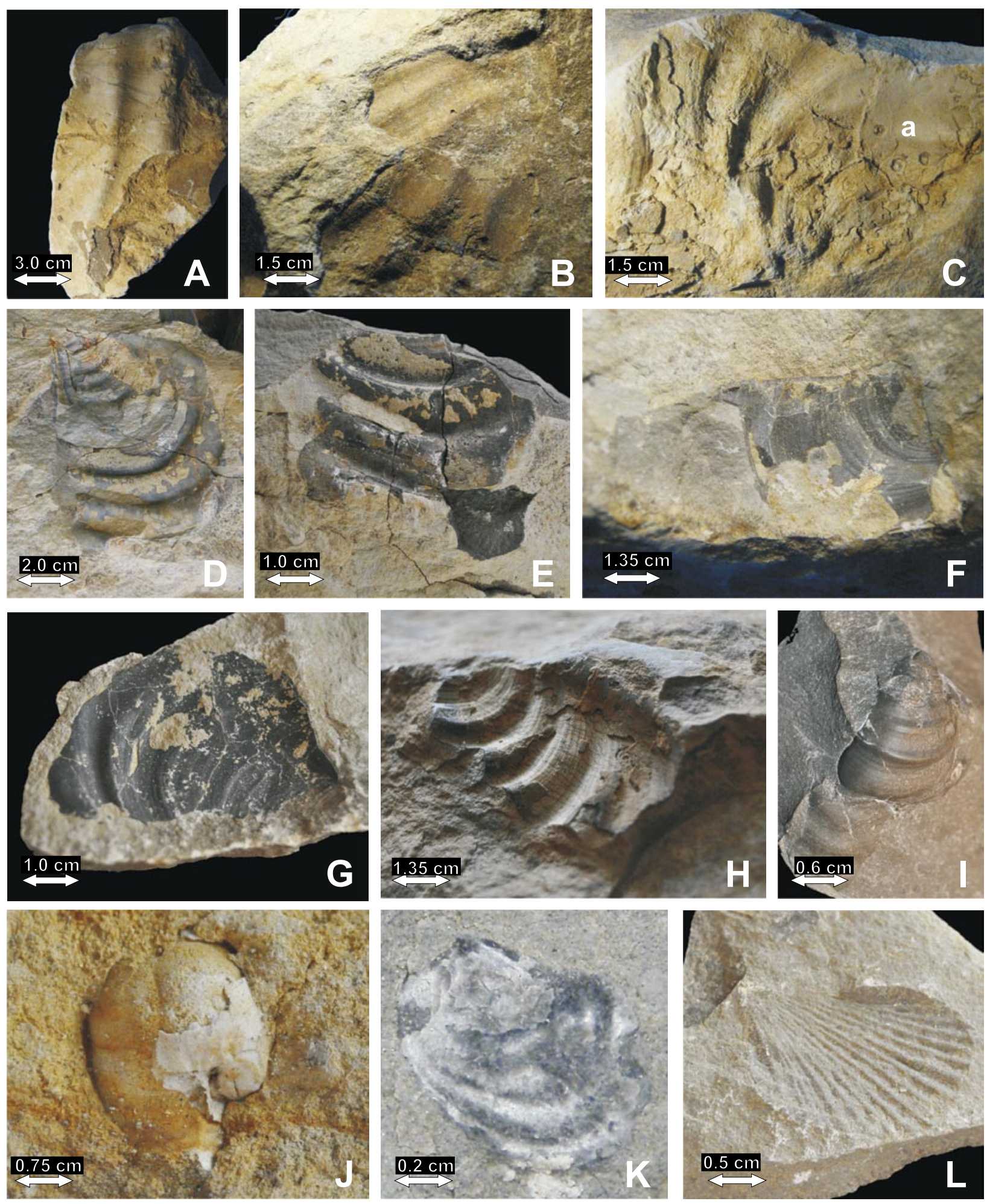

Fig. 8. Inoceramids and other bivalves from the Middle Turonian of the Stara Bystrzyca quarry.

A-C: Inoceramus cuvieri Sowerby (MGU.Wr-5455s through MGUWr-5457s); a) gastropods prints; D-H: Inoceramus lamarcki Parkinson (MGUWr-5458 through 5462s); I: Inoceramus lamarcki Parkinson, from the collection of the Geological Museum of Wrocław University (collection: Rafał Janek, MGUWR-5487s); J: Exogyra cornuarietis NilssonGriepenkerl (MGUWr-5465s); K: Exogyra sp. (MGUWr-5467s); L: Lima canalifera Goldfuss (MGUWr-5473s). 


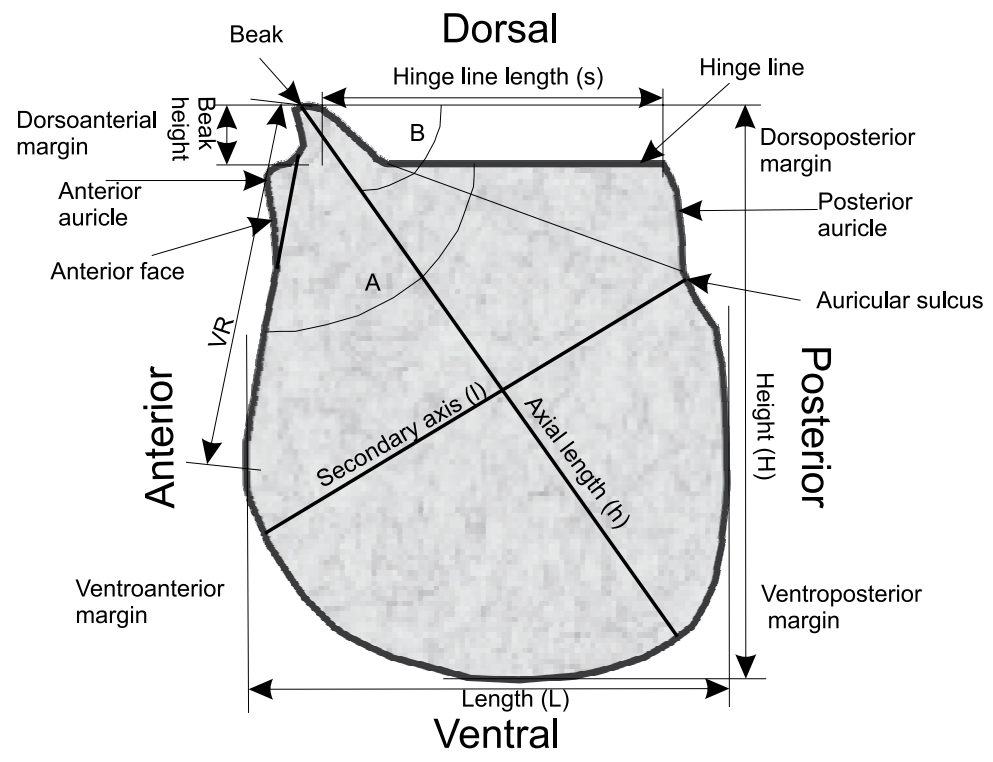

A Anterior hinge angle

$B$ Angle of growth axis

VR Length of anterior margin

\begin{tabular}{|c|c|c|c|c|c|c|c|}
\hline specimens & length(L) & height $(\mathrm{H})$ & $\begin{array}{c}\text { axial } \\
\text { length }(h)\end{array}$ & $\begin{array}{c}\text { secondary } \\
\text { axis (I) }\end{array}$ & $\begin{array}{c}\text { beak } \\
\text { height (bh) }\end{array}$ & $\begin{array}{c}\text { anterior } \\
\text { hinge angle } \\
\text { (A) }\end{array}$ & $\begin{array}{l}\text { anterior } \\
\text { margin } \\
\text { (VR) }\end{array}$ \\
\hline L.cuvieri; MGUWr-5454s & $6.0 \mathrm{~cm}$ & $6.5 \mathrm{~cm}$ & $6.0 \mathrm{~cm}$ & $7.0 \mathrm{~cm}$ & - & - & -1 \\
\hline I.lamarcki; MGUWr-5458s & $7.0 \mathrm{~cm}$ & $8.5 \mathrm{~cm}$ & $10.0 \mathrm{~cm}$ & $8.0 \mathrm{~cm}$ & $0.8 \mathrm{~cm}$ & $105^{\circ}$ & $3 \mathrm{~cm}$ \\
\hline I.lamarcki; MGUWr-5460s & $6.0 \mathrm{~cm}$ & $6.0 \mathrm{~cm}$ & $8.0 \mathrm{~cm}$ & $6.0 \mathrm{~cm}$ & - & $95^{\circ}$ & $3 \mathrm{~cm}$ \\
\hline I.lamarcki; MGUWr-5461s & $4.5 \mathrm{~cm}$ & $5.0 \mathrm{~cm}$ & $5.0 \mathrm{~cm}$ & $4.0 \mathrm{~cm}$ & - & $110^{\circ}$ & $1.5 \mathrm{~cm}$ \\
\hline I.lamarcki; MGUWr-5487s & $3.5 \mathrm{~cm}$ & $7.0 \mathrm{~cm}$ & $7.5 \mathrm{~cm}$ & $5.5 \mathrm{~cm}$ & - & $85^{\circ}$ & $3.0 \mathrm{~cm}$ \\
\hline
\end{tabular}

Fig. 9. Morphological features of an inoceramid shell according to Walaszczyk \& Wood (1998) and Walaszczyk et al. (2004a), slightly changed. The table shows the values of these features for the specimens of Inoceramus cuvieri and I. lamarcki under investigation.

Numerous imprints of gastropods are preserved on the internal moulds; their diameters range from $1.5 \mathrm{~mm}$ to $3.5 \mathrm{~mm}$ and in some cases even reach $1 \mathrm{~cm}$ (Fig. $6 \mathrm{M}$; Fig. $8 \mathrm{C}$ ). Fragments of shells, preserved on the internal moulds or in the rock, are 3-5.5 mm thick (on some specimens they are thinner: $1.5-2 \mathrm{~mm}$ ).

\section{Occurrence}

Inoceramus cuvieriSowerby is known from the Middle Turonian and the lower Upper Turonian of the Opole Trough (Poland), the Turonian of England, the Middle and Upper Turonian of the Carpathians, Germany, the Czech Republic, Canada and the USA (Tarkowski 1991). It is also known from the Upper Turonian of Russia and Ukraine (Donbas, Crimea, Caucasus), Kazakhstan (Mangyshlak) and Kamchatka. According to Mitura (1957), I. cuvieri occurs in the Middle Turonian (Inoceramus lamarcki Zone) in the Łódź Synclinorium (Poland) and in the Upper Turonian of England and Germany. Herman \& Spicer (1997) mentioned I. cuvieri from the Upper Turonian of NE Russia. Robaszyński et al. (2005) described Inoceramus cuvieri from the Middle Turonian of the Paris Basin (France). Summesberger et al. (1999) reported I. cuvieri from the Upper Turonian of Austria.

\subsubsection{Inoceramus lamarcki Parkinson, 1819 \\ (Fig. 8 D-I)}

1974. Inoceramus lamarcki Parkinson; R. Marcinowski, pl. 25, figs $2 \mathrm{a}, \mathrm{b}$

1984. Inoceramus lamarcki Parkinson; L. Malinowska, p. 362, pl. 156, fig. 1

1988. Inoceramus lamarcki lamarcki Parkinson; I. Walaszczyk, pl. 3, figs 1,6

1991. Inoceramus lamarcki lamarcki Parkinson; R. Tarkowski, pp. 111-112, pl. 7, figs1,3; pl. 8, figs $2-4$

1992. Inoceramus lamarcki Parkinson; I. Walaszczyk, pp. 30-31, pl. 9, figs 4-7; pl. 10, figs 1-3; pl. 11, figs 1,4

For a comprehensive synonymy, see Walaszczyk (1988) and Tarkowski (1991). 


\section{Material}

6 specimens, No MGUWr- 5458 to MGUWr-5462; MGUWr-5487s), stored at the Geological Museum of Wrocław University. Three almost complete shells, two entirely preserved moulds and some pieces of shells.

\section{Specimens' descriptions}

The medium-sized specimens have triangular outlines and rounded edges. The shells are moderately convex; sometimes they are inflated. The specimens are $3.5-7.0 \mathrm{~cm}$ long and $5.0-8.5 \mathrm{~cm}$ high; their axial lengths range from $5.0 \mathrm{~cm}$ to $10.0 \mathrm{~cm}$ and their secondary axes from 4.0 to $8.0 \mathrm{~cm}$ (see the morphological features of the inoceramid shell in Fig. 9). The beak is pointed, slightly projecting above the hinge line (beak height: $0.8 \mathrm{~cm}$ ). The apical angle (anterior hinge angle) varies from $85^{\circ}$ to $110^{\circ}$. The most characteristic feature is the occurrence of distinct (weak to strong) concentric, subrounded ribs, regularly increasing in size with relatively wide, flat interspaces. In the juvenile part, they are more or less regularly spaced, while their interspaces gradually increase (from $0.5 \mathrm{~cm}$ to $1.5 \mathrm{~cm}$ ) towards the ventral side of the shell in the adult part.

The rugae are the strongest developed in the anterio-ventral, ventral and ventro-posterior part of the shell (Fig. 8 D, G-I). They become gradually weaker developed when passing onto the dorsal part of the valve. The growth rings (rugae) and spaces between them are covered with poorly visible growth lines, which are more or less symmetrically distributed. The distance between the growth lines increases towards the ventral side and ranges from 1.0 to $4.0 \mathrm{~mm}$. The growth lines are well preserved, and rather straight (not 'jagged' as in specimens described as I. cuvieri). They are parallel to the rugae.

These specimens (Fig. 8 D-I) differ in the general outline and pattern of their surface ornament, especially with regard to the growth lines, from specimens recognized as I. cuvieri. They show a close similarity to I. lamarcki.

\section{Occurrence}

Inoceramus lamarcki Parkinson is known from the Middle Turonian of Poland (Opole Synclinorium: Opole, Krzanowice; Miechów Synclinorium; Tarkowski, 1991). It has also been described from the Middle Turonian of England, France, Germany, India and Madagascar. It occurs in the Middle and Upper Turonian of Germany, in the Middle Turonian to the Coniacian in England, and in the Upper Turonian of the East European Platform and Asia (Donbas, Crimea, Caucasus, Mangyshlak and Kamchatka). Walaszczyk (1992) described this species from the Middle to lower Upper Turonian deposits of the Central Polish Uplands.

\subsection{Other fossils}

In addition to the ammonite Lewesiceras peramplum Mantell and the inoceramids Inoceramus cuvieri Sowerby and I. lamarcki Parkinson, the Middle Turonian sandy and marly limestones with intercalations of siliceous-clayey beds of Stara Bystrzyca contain also other bivalves: Exogyra cornuarietis Nilson-Griepenkerl (Fig. 8 J), Exogyra sp. (Fig. 8 K), Lima canalifera Goldfuss (Fig. 8 L), Lima elongata Geinitz (Fig. 10 A-B, E), Lima granulata Nilsson (Fig. 10 C-D), Pecten membranaceus Nilsson (Fig. 10 G), Pecten virgatus Nilsson (Fig. 10 F). Further, the brachiopod Terebratula semiglobosa Sowerby (Fig. 10 $\mathrm{H})$ is present. The assemblage of trace fossils comprises ?Chondrites isp. (Fig. 10 I), Planolites beverleyensis (Fig. $10 \mathrm{~J}$ ) and Pl. montanus (Fig. $10 \mathrm{~K}-\mathrm{L})$.

The majority of these taxa were already described by Scupin (1912-1913), Geinitz (1843), Andert (1934) from other outcrops of the Middle Turonian in the Nysa Kłodzka Graben, the Intra-Sudetic Synclinorium and the North Sudetic Synclinorium. Inoceramids were described from Poland (and other countries) by Walaszczyk $(1988,1992)$, Walaszczyk \& Wood (1998), Walaszczyk et al. (2004a,b) and Zonova \& Yazykowa (1998).

The Stara Bystrzyca quarry yielded also fragments of sponges, gastropods and an assemblage of mostly benthic calcareous and agglutinated foraminifers (Table 1; Fig. 11). A similar assemblage of foraminiferal benthos and plankton has been described from the Upper Turonian of the Bohemian Cretaceous Basin (Vodrážka et al., 2009). 

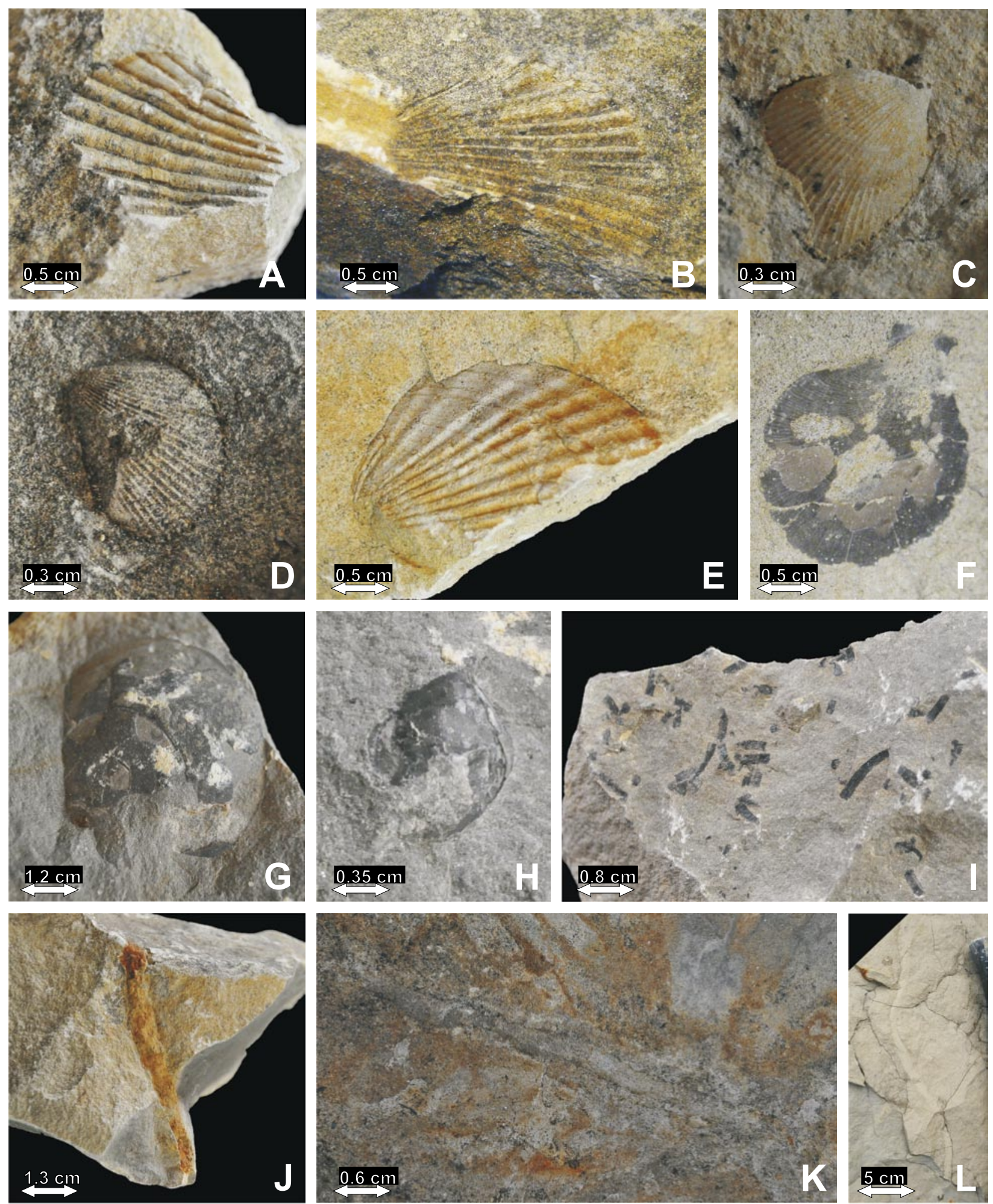

Fig. 10. Bivalves and trace fossils from the Middle Turonian of the Stara Bystrzyca quarry.

A-B: Lima elongata Geinitz (MGU.Wr - 5475s through MGUWr-5476s); C-D: Lima granulata Nilsson (MGUwr-5477s through MGUWr-5478s); E: Lima elongata Geinitz (MGUWr-5479s); F: Pecten virgatus Nilsson (MGUWr-5480s); G: Pecten membranaceus Nilsson (MGUWr-5481s); H: Terebratula semiglobosa Sowerby (MGUWr-5482s); I: ?Chondrites isp. (MGUWr-5483s); J: Planolites beverleyensis (MGUWr-5484s); K-L: Planolites montanus. 
Table 1. Stratigraphic ranges of the foraminifer assemblage in the Middle Turonian deposits of the Stara Bystrzyca quarry.

\begin{tabular}{|c|c|c|c|c|c|c|c|c|c|}
\hline \multirow{2}{*}{ Foraminifers taxa } & \multicolumn{2}{|c|}{ Cenomanian } & \multicolumn{3}{|c|}{ Turonian } & \multicolumn{2}{|c|}{ Coniacian } & \multicolumn{2}{|c|}{ Santonian } \\
\hline & Lower & Upper & Lower & Middle & Upper & Lower & Upper & Lower & Upper \\
\hline \multicolumn{10}{|c|}{ Frondicularia verneuiliniana d'Orbigny } \\
\hline \multirow{2}{*}{\multicolumn{10}{|c|}{ Gaudryina laevigata Franke }} \\
\hline & & & & & & & & & \\
\hline \multirow{2}{*}{\multicolumn{10}{|c|}{ Gavelinella ammonoides Reuss }} \\
\hline & & & & & & & & & \\
\hline \multicolumn{10}{|l|}{ Gavelinella moniliformis Reuss } \\
\hline \multirow{2}{*}{\multicolumn{10}{|c|}{ ? Globorotalites subconicus Morrow }} \\
\hline & & & & & & & & & \\
\hline \multicolumn{10}{|l|}{ Heteroxelix striata Ehrenberg } \\
\hline \multirow{2}{*}{\multicolumn{10}{|c|}{ Nodosaria cf. monile Hagenow }} \\
\hline & & & & & & & & & \\
\hline \multicolumn{10}{|c|}{ Quadrimorphina allomorphinoides Reuss } \\
\hline \multirow{2}{*}{\multicolumn{10}{|c|}{ Reophax sp. }} \\
\hline & & & & & & & & & \\
\hline \multicolumn{10}{|l|}{ Spiroplectammina praelonga Reuss } \\
\hline \multirow{2}{*}{\multicolumn{10}{|c|}{ Stensioeina granulata Olbertz }} \\
\hline & & & & & & & & & \\
\hline Textularia foeda Reuss & & & & & & & & & \\
\hline
\end{tabular}

stratigraphic ranges in the Nysa Kłodzka Graben according to Jerzykiewicz and Teisseyre (1974); Teisseyre (1975); Gawor-Biedowa (1980)

stratigraphic distribution in the North Sudetic Synclinorium after Teisseyre (1992)

6. Stratigraphy of the Stara Bystrzyca limestones

The Nowa Bystrzyca limestones belong to the second level of marls (the siliceouscalcareous marls, Inoceramus lamarcki Zone) that overlie the Quader Sandstone (Fistek \& Gierwielaniec, 1957, 1964). The first level of marls (the sandy marls, Inoceramus lamarcki Zone) is present below the sandstone. Wroński \& Cwojdziński (1984), in their explanation to sheet Bystrzyca Kłodzka of the Polish geological map (Wroński, 1981), also mentioned a first marl level of $10 \mathrm{~m}$ thick and a second one of 50 $\mathrm{m}$ thick; these two levels are separated by the Quader Sandstone (50-60 m).

The most relevant for the biostratigraphy of the Stara Bystrzyca limestone are the inoceramids (Inoceramus cuvieri, I. lamarcki); the foraminifers are less important. The inoceramids Inoceramus cuvieri Sowerby and I. lamarcki Parkinson are common in the Stara Bystrzyca quarry and have enormous sizes (Fig. 8 A-C). According to numerous authors, I. cuvieri was the most widespread during the middle and upper Middle Turonian (see Walaszczyk, 1992). The second inoceramid, I. lamarcki, that also abounds in the Stara Bystrzyca quarry, is typical of the upper part of the Middle Turonian (Walaszczyk, 1992). The joint occurrence of both I. cuvieri and I. lamarcki indicates a position in the upper part of the Inoceramus lamarcki Zone (uppermost Middle Turonian). Because of the common presence of I. cuvieri Sowerby and I. lamarcki Parkinson, one may assign the Stara Bystrzyca limestones to the upper Middle Turonian (upper part of the Inoceramus lamarcki Zone).

Thin-section analysis of the foraminifers allows only an approximate dating of the sandy and marly limestones because most taxa have long stratigraphic ranges; some foraminifers (Stensioeina granulata Olbertz, Heteroxelix striata Ehrenberg, Spiroplectammina praelonga Reuss), however, are known from middle Middle Turonian of the Nysa Kłodzka Graben (Table 1), thus suggesting a middle Middle Turonian age or younger for the sandy, marly limestones and siliceous-clayey beds. Teisseyre (1992) defined 

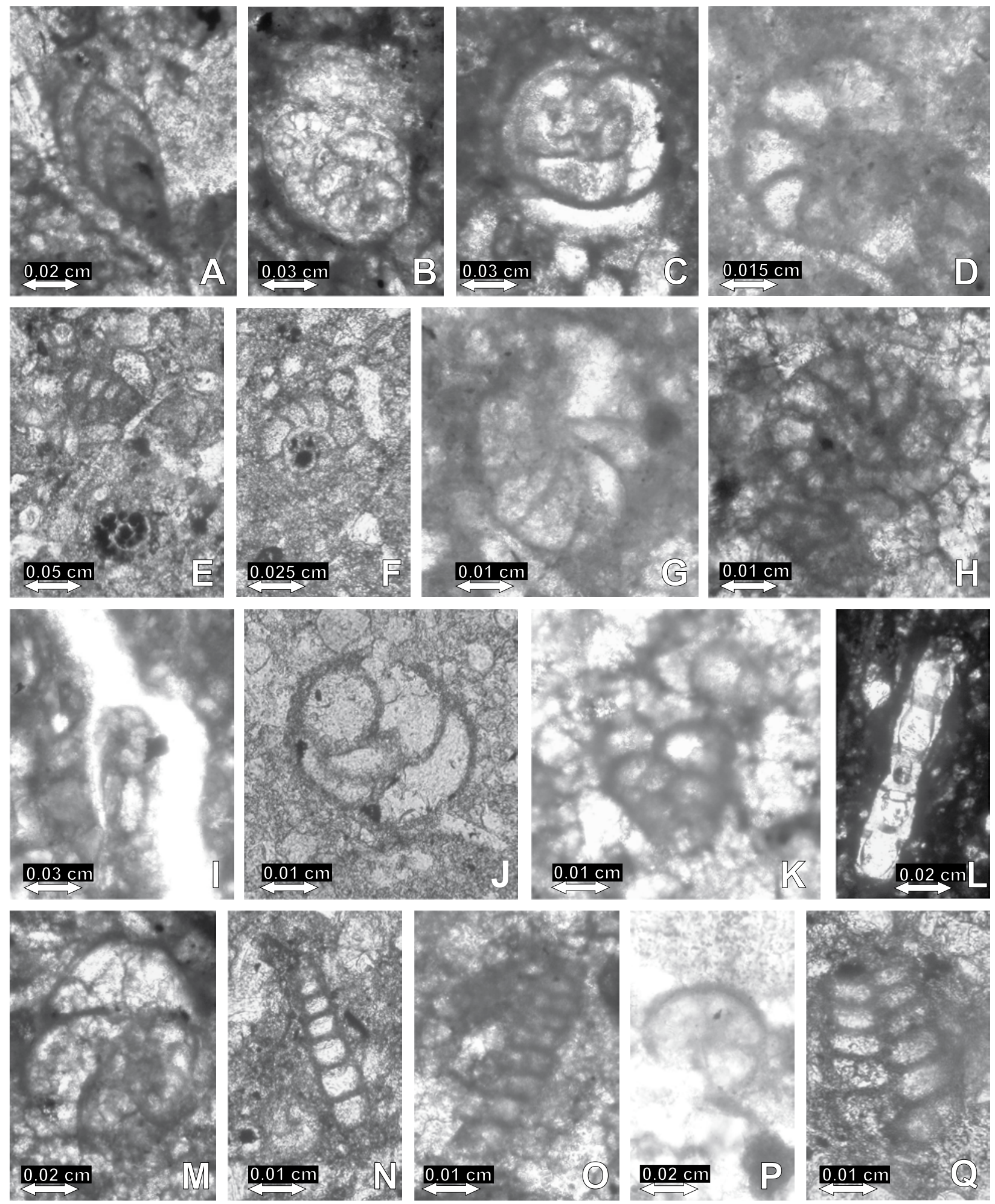

Fig. 11. Assemblage of foraminifers from the Middle Turonian, Stara Bystrzyca quarry.

A: Frondicularia verneuiliniana d'Orbigny; B-C: Gaudryina laevigata Franke; D: Gavelinella moniliformis Reuss; E-F: Gavelinella ammonoides Reuss; G-H: Gavelinella moniliformis Reuss; I: ?Globorotalites subconicus Morrow; J-K: Heteroxelix striata Ehrenberg; L: Nodosaria cf. monile Hagenow; M: Quadrimorphina allomorphinoides Reuss; N: Reopax sp.; O: Spiroplectammina praelonga Reuss; P: Stensioina granulata Olbertz; Q: Textularia foeda Reuss. 
the Gavelinella moniliformis - Gaudryina Zone in the North Sudetic Synclinorium; it comprises the latest Lower Turonian to Lower Coniacian. The Bystrzyca limestone could belong to a correlatable zone in the Nysa Kłodzka Graben. The Gavelinella moniliformis Zone was also distinguished by Walaszczyk et al. (2004a) in the Middle Turonian of central European Russia.

The Inoceramus lamarcki Zone and the same age (the upper part of the Inoceramus lamarcki Zone) is also indicated by studies carried out by Radwański (1964), who mentioned the presence of large forms of I. cuvieri in the upper Middle Turonian. On the other hand, German and Polish geologists found I. cuvieri in the uppermost Turonian and assigned it to the Inoceramus schloenbachi Zone (Flegel, 1904; Scupin, 1907, 1912-1913, 1935, 1936). Kędzierski (2005) noticed that the Turonian, as understood by the authors, comprised also a part of the Coniacian. A similar situation occurred in the North Sudetic Synclinorium (Chrząstek, 2008a). This may have resulted in erroneous datings of sediments that contain I. cuvieri. Moreover, according to current views, I. schloenbachi Bohm (the present Cremnoceramus crassus crassus) denotes the Coniacian.

\section{Reconstruction of the palaeoenvironment and palaeoecology}

The fauna assemblage in the Middle Turonian sandy and marly limestone is indicative of a shallow-marine basin. The bivalves including inoceramids, and most of all oysters, gastropods, sponges, the predominance of benthic foraminifers, as well as the trace fossils, also point to a shallow basin.

The ammonites were probably stenotopic organisms, very sensitive to environmental changes (e.g. oxygenation level, salinity) (Tsujita \& Westermann, 1998; Landman et al., 2012; Olivero, 2012). According to Zakharov et al. (2012), remains of ammonites shells are common in Mesozoic epicontinental seas, but rare in oceanic successions. On the other hand, Olivero (2012) reported that the number of am- monite specimens in both shallow- and deepmarine facies is almost the same. According to Matsukawa et al. (2012), Early Cretaceous ammonites inhabited near-shore, intermediate and distal-shelf to upper-slope environments.

Stevens (1988) correlated the presence of large ammonites with eustatic sea-level fluctuations (e.g. Cenomanian-Turonian). He reported that large ammonites lived in the deepsea and migrated into more shallower settings during rising sea levels. On the other hand, Klug (2002), who examined Emsian and Eifelian ammonites, reported that $70 \%$ of the giant ammonites were found in layers which were deposited in shallow environments.

In the Stara Bystrzyca quarry, the abundant inoceramids, represented mainly by Inoceramus cuvieri Sowerby (Fig. $6 \mathrm{M}$, Fig. 8 A-C) and I. lamarcki Parkinson (Fig. 8 D-I) consist mainly of fragments that reached lengths of $20 \mathrm{~cm}$, indicating that these forms must have been quite large. The largest piece of an inoceramid shell found in this quarry measures $40 \mathrm{~cm}$ (J. Wojewoda, Wrocław University, pers. comm. 2011). According to Hilbrecht \& Harries (1996), Ozanne \& Harries (2002) and Walaszczyk et al. (2004a), inoceramids have a large ecological tolerance: they are cosmopolitan and may live in various environments. Inoceramids are known from well-oxygenated, shallow-marine to poorly oxygenated, deep-marine settings (Harries \& Ozanne 1998; Ozanne \& Harries, 2002; Olivero, 2012). According to these authors, inoceramids prefer oxygen-depleted shelf environments, but can also thrive in welloxygenated settings, including shallow-marine facies.

Ozanne \& Harries (2002) and Kumagae et al. (2011) reported a cosmopolitan distribution of inoceramids in Mesozoic marine environments. According to Zonova \& Yazykova (1998), the maximum diversity of inoceramids and ammonites was in the Late Turonian. Inoceramids abounded and exhibited a great taxonomical diversity during the Middle Turonian, at the beginning of a regressive cycle. On the other hand, the occurrence of ammonites correlates with transgressive peaks. During the regressive cycles they started to loose their taxonomical diversity, due to the reduction of the 
extent of the shelf areas (Zonova \& Yazykova, 1998; Olivero, 2012).

Radwański (1964) reported that gigantic forms occurred in the upper part of the Middle Turonian, particularly Inoceramus cuvieri Sowerby, which are the most common representatives of the inoceramid fauna in the Bystrzyca beds and which can reach a size of $1 \mathrm{~m}$. Maybe these specimens correlate with Inoceramus hercules (Heinz) (see Summesberger et al., 1999). According to Radwański (1964), the dominance of giant inoceramids could be a sign of an approaching change of environmental conditions that resulted in the stoppage of the inflow of larval forms. The absence of competition for food with others marine animals enabled the already existing individuals to reach large sizes. According to Radwański (1964), the uppermost beds of the Middle Turonian (Terebratula semiglobosa Zone) were deposited under much worse living conditions for the inoceramids, as large inoceramid specimens are rarely encountered in these beds.

Kauffman et al. (2007) described Middle Coniacian-Lower Campanian platyceramids, which commonly reach sizes of over 1 or even $2 \mathrm{~m}$. These giant (chemosymbiotic) types are especially common in calcareous, dysoxic facies with abundant pyrite (Olivero, 2012). According to this author, they have smaller sizes in oxygenated environments. The giant platyceramids prefer settings with a low sedimentation rate and slow bottom currents.

Trace fossils are not common in limestone deposits. Their assemblage in the Stara Bystrzyca quarry (Planolites montanus, Planolites beverleyensis, and ?Chondrites) (Fig. $10 \mathrm{I}-\mathrm{L}$ ) belongs to the Cruziana ichnofacies sensu Seilacher (Seilacher, 1967; MacEachern et al., 2007). Ichnoassemblages comprising Chondrites are usually referred to as representing oxygen-deficient conditions (Twitchett \& Wignall, 1996; Uličný et al., 1997; Wetzel \& Uchman, 2001; Giannetti \& McCann, 2010; Rodríguez-Tovar \& Uchman, 2010; Zonneveld et al., 2010; Gingras et al., 2011).

Chondrites itself is commonly known as an indicator of poor oxygenation (dysaerobic-exaerobic conditions) (McCann, 1990; Bromley, 1996; Savary et al., 2004; Uchman et al., 2008;
Carmona et al., 2009; Knaust, 2009; Giannetti, 2010; Wetzel et al., 2011; Monaco et al., 2012). The Chondrites producers tolerate and perhaps even prefer oxygen-deficient conditions, even anoxia, as well as changes in salinity (Bromley \& Ekdale, 1984; Savrda \& Bottjer 1986; Allington-Jones et al., 2010; Cummings \& Hodgson, 2011). According to Allington-Jones et al. (2010), the occurrence of Chondrites commonly coincides with an abundance of pyrite. This holds also true for the Stara Bystrzyca quarry, where pyrite mineralizations in marly limestone occur.

According to Malpas et al. (2005), Wetzel \& Reisdorf (2007) and Carmona et al. (2009), the ichnoassemblage comprising Chondrites and Planolites suggests low-energy settings, a low sedimentation rate and deposition in the deepest part of the basin, in an environment with a low oxygen content (offshore shelf).

However, Planolites is a facies-crossing ichnotaxon which has been documented from almost all marine and continental environments (Hofmann et al., 2011). Planolites can appear in fully marine environments but the tracemaker can live under oxygen-deficient conditions (Martin, 2004; Chen et al., 2011). The tracemakers of Planolites and Palaeophycus need a fairly low oxygen level in the bottom water (Savrda \& Bottjer, 1986; Savrda, 2007; Szulc, 1990, 2000; Chrząstek, 2008b,c; Rodríguez-Tovar et al., 2009; Boyer \& Droser, 2011). According to Szulc (1990), the Planolites-Palaeophycus assemblage is characteristic of poorly-oxygenated conditions during transgressive maxima. On the other hand, Planolites can appear also in well-oxygenated environments (Savrda, 1995; Giannetti \& McCann, 2010; Gingras et al., 2011; Hofmann et al., 2011; Phillips et al., 2011).

The sequential appearance of Chondrites Planolites - Thalassinoides indicates increasing oxygenation (Bromley, 1996; Etter, 1996; Savrda, 2007; Monaco et al., 2012). The tracemakers of Chondrites prefer stenohalic conditions (MacEachern \& Gingras, 2007), while the producers of Planolites are common in fully marine and brackish settings. On the other hand, the producers of Chondrites can also be able to survive when the salinity decreases (AllingtonJones et al., 2010). 
In summary, the Chondrites-Planolites association is environmentally tolerant and occurs in different settings (McCann, 1990). It is particularly dominant in the deeper part of the basin (offshore shelf) and indicates low-oxygen conditions and a normal marine salinity.

In the Middle Turonian Bystrzyca and Długopole Sandstones appears an ichnoassemblage comprising mainly Ophiomorpha nodosa, Thalassinoides suevicus, Thalassinoides paradoxicus, Curvolithus and ?Macaronichnus sp., typical of well-oxygenated, high-energy, shallow-marine environments. These trace fossils appear in the intertidal to shallow subtidal (foreshore-shoreface) part of the Skolithos ichnofacies (MacEachern et al., 2007; D'Alessandro \& Uchman, 2007) and are considered to represent a deltaic environment. In the Middle Turonian sandy and marly limestones, the assemblage of trace fossils comprising only ?Chondrites, Planolites beverleyensis and Planolites montanus (Cruziana ichnofacies) suggests sedimentation in a slightly deeper basin. These trace fossils are characteristic of environments with a low rate of sedimentation, and probably less oxygenated conditions. Chondrites-Planolites assemblages are typical of offshore shelf settings (Kędzierski \& Uchman, 2001; MacEachern et al., 2007; McIlroy, 2007).

On the basis of the fossil assemblage in the Middle Turonian, especially the inoceramids, oysters and trace fossils, one can deduce that the sandy limestones and marls were deposited in a deeper part of the basin (offshore shelf) than the Bystrzyca and Długople Sandstones of the same age. The sedimentation probably took place in a moderate- to low-energy environment with normal marine salinity and occasionally oxygen-deficient conditions.

\subsection{Palaeogeographic setting}

During the Cenomanian, the sea transgressed to the Nysa Kłodzka Graben from the SW (Bohemian Basin) and from the E (Opole Basin) and land masses became almost entirely flooded during the Early Turonian (Wojewoda, 1997; Biernacka \& Józefiak, 2008, 2009). In the Intra-Sudetic Basin, the Nysa Kłodzka Graben and northern parts of the Bohemian Cretaceous Basin, silts and clays were deposited during the Early Turonian (Jerzykiewicz, 1975). In the Middle Turonian, a regression started, but it was interrupted by several phases of increased subsidence (Wojewoda, 1997; Rotnicka, 2005, 2007). A sandy facies developed first in the Middle Turonian (Bystrzyca and Długopole Sandstones). The clastic material of which the sandstones are built, was derived from the massifs that were being uplifted: the East Sudetic Island (Jerzykiewicz, 1975; Wojewoda, 1997). Don and Don (1960) and Radwański (1964, 1968) mention also Orlica Island as a possible source, but Chrząstek \& Wojewoda (2011) suggest an Orlica uplift instead of an Orlica Island. The sandstones thin from the NE towards the SW and finally pinch out within calcareous deposits that accumulated in a deeper part of the basin. The transport was directed from North to South and from North-West to South-East. The Bystrzyca and Długopole Sandstones are interpreted as delta deposits (Uličný, 2001; J. Wojewoda, Wrocław University, pers. comm. 2011).

During the Middle Turonian the - until then - single marine basin was divided into a northern basin (with a connection to the North Sea and Atlantic) and a southern basin (with a connection to the Bohemian Basin and the Tethys) (Gawor-Biedowa, 1980; Chrząstek \& Wojewo$\mathrm{da}, 2011$ ). At the Turonian/Coniacian transition, another transgression started. The Cretaceous marine sediments of the Nysa Kłodzka Graben record two transgression maxima, one in the Early Turonian and another one during the late Turonian-Early Coniacian (GaworBiedowa, 1980; Schoeneichowa-Jaskowiak \& Krassowska, 1988; Teisseyre, 1992, Wojewoda, 1997). The second transgressive maximum is better recorded, because it was due to the maximum subsidence in the area of the Nysa Kłodzka Graben (Jerzykiewicz, 1971, 1975; Wojewoda, 1997; Niedźwiedzki \& Salamon, 2005). The transgressive cycles of the Cretaceous Nysa Kłodzka Graben sea fit the European bathymetrical curves of Hancock \& Kauffman (1979), Haq et al. (1987), Hancock (1990) and Hancock \& Walaszczyk (2004). 


\section{Conclusions}

Investigation of sandy and marly limestones with intercalations of siliceous-clayey beds in the Stara Bystrzyca quarry yielded a specimen of Lewesiceras peramplum Mantell with a diameter $45 \mathrm{~cm}$ (because a part of a whorl is missing the complete specimen must have measured some $49 \mathrm{~cm}$ ). This species has not been described earlier from the Middle Turonian sediments of the Nysa Kłodzka Graben area.

A second ammonite, assigned ?Lewesiceras sp. (diameter: $33 \mathrm{~cm}$ ), has been found by Radwańska in the middle of the $20^{\text {th }}$ century in ?Coniacian deposits of the graben, at Wilkanów (S. Cwojdziński, PGI-PRI Wrocław, pers. comm. 2011). Pachucki (1959) mentioned Pachydiscus aff. peramplus Mantell from the Emscherian of the graben.

Large specimens (up to $20 \mathrm{~cm}$ ) of the inoceramids I. cuvieri Sowerby and I. lamarcki Parkinson also occur. The largest inoceramid shell ever found in the Stara Bystrzyca quarry has a diameter of $40 \mathrm{~cm}$ (J. Wojewoda, Wrocław University, pers. comm. 2011).

Other bivalves (including oysters) occur as well: Exogyra cornuarietis Nilsson-Griepenkerl, Exogyra sp., Lima canalifera Goldfuss, Lima elongata Geinitz, Lima granulata Nilsson, Pecten membranaceus Nilsson, and Pecten virgatus Nilsson. In addition, fragments of sponges, gastropods and brachiopods (Terebratula semiglobosa Sowerby) are present, as well as an assemblage of trace fossils (?Chondrites isp., Planolites beverleyensis, Planolites montanus). Thin sections show abundant foraminifers, sponge spiculae, bryozoans, ostracods and gastropods (Table 1 ).

The fauna, particularly the inoceramids and to a lesser degree the foraminifers, makes it possible to date the sediments as upper Middle Turonian (upper part of the Inoceramus lamarcki Zone) (Fig. 2 B).

The sandy and marly limestones with intercalations of siliceous-clayey beds in the Stara Bystrzyca quarry were deposited in a shallowmarine basin (offshore shelf) but in deeper parts than the Middle Turonian Bystrzyca and Długopole Sandstones, which are interpreted as delta deposits (foreshore-shoreface). This conclusion is based on the fossil assemblage, but it should be kept in mind that the trace fossils, representing the Cruziana ichnofacies, point to a slightly deeper environment. Both the macro- and trace fossils suggests a moderate- to low-energy environment with normal marine salinity and occasionally poorly oxygenated water.

Two distinct transgressive maxima (Early Turonian and Early Coniacian) took place in the Nysa Kłodzka Graben and adjacent area, whereas a regression culminated during the Middle and Upper Turonian. The transgressive cycle of the Late Cretaceous in the Nysa Kłodzka Graben is consistent with the global sea-level fluctuations indicated by Haq et al. (1987).

\section{Acknowledgements}

I am very greatful to E. Jagt-Yazykova and $M$. Machalski for valuable insights that helped to correctly assign the ammonite found by Z. Radwańska. William Jim Kennedy (Oxford University) is thanked for taxonomical revision of the ammonite ?Lewesiceras sp. I thank very much P. Aleksandrowski (Polish Geological Institute - Polish Research Institute, Wrocław) for agreeing to use the PGl-PRI ammonite specimens for my research, and S. Cwojdziński (PGI-PRI, Wrocław) and J. Wojewoda (Wrocław University) for information concerning fossils. The author would like also to thank R. Niedźwiedzki (Wrocław University) for fruitful discussions and M. Awdankiewicz (Wrocław University) for petrographic consultation. M. Niedźwiecki, supervised by the present author, gathered part of the fossil collection during his M.Sc. field work. The investigations were supported by grants $2374 / \mathrm{W} /$ ING/10 and 1017/S/ING/10-IV/ach.

\section{References}

Allington-Jones, L., Braddy, S.J. \& Trueman, C.N., 2010. Palaeoenvironmental implications of the ichnology and geochemistry of the Westbury Formation (Rhaetian), Westbury-on-Severn, South-West England. $\mathrm{Pa}$ laeontology 53, 491-506.

Andert, H., 1934. Die Kreideablagerungen zwischen Elbe und Jeschken. Teil III: Die Fauna der obersten Kreide in Sachsen, Böhmen und Schlesien. Abhandlungen der Preussischen Geologischen Landesanstalt 159, 477 pp. 
Ayyasami, K., 2006. Role of oysters in biostratigraphy: a case study from the Cretaceous of the Ariyalur area, southern India. Geosciences Journal 10, 237-247.

Biernacka, J. \& Józefiak, M., 2008. Kilka uwag o tzw. wyspie wschodniosudeckiej na podstawie piaskowców z Jerzmanic Zdroju (dolny turon, niecka północnosudecka) [A few comments on the so-called East Sudetic Island on the basis of the Jerzmanice Zdrój sandstones (Lower Turonian, North Sudetic Basin)]. [In:] J. Wojewoda (Ed.): Baseny Śródgórskie, Kontekst regionalny środowisk i procesów sedymentacji, Kudowa Zdrój, 1-2.

Biernacka, J. \& Józefiak, M., 2009. The Eastern Sudetic Island in the Early-to-Middle Turonian: evidence from heavy minerals in the Jerzmanice sandstones, SW Poland. Acta Geologica Polonica 59, 545-565.

Boyer, D.L. \& Droser, M.L., 2011. A combined trace- and body-fossil approach reveals high-resolution record of oxygen fluctuations in Devonian seas. Palaios 26, 500-508.

Bromley, R.G., 1996. Trace fossils - biology, taphonomy and applications. Chapman \& Hall, London, 347 pp.

Bromley, R.G. \& Ekdale, A.A., 1984. Chondrites: a new fossil indicator of anoxia in sediments. Science 224, 872-874.

Carmona, N.B., Buatois, L.A., Ponce, J.J. \& Mángano, M.G., 2009. Ichnology and sedimentology of a tideinfluenced delta, Lower Miocene Chenque Formation, Patagonia, Argentina: trace-fossil distribution and response to environmental stresses. Palaeogeography, $\mathrm{Pa}$ laeoclimatology, Palaeoecology 273, 75-86.

Čech, S., 1989. Upper Cretaceous Didymotis events from Bohemia. [In:] J. Wiedman (Ed.): Cretaceous of the Western Tethys. Proceedings of the $3^{\text {rd }}$ International Cretaceous Symposium (Tübingen 1987). Stuttgart, 657-676.

Chen, Z.-Q., Tong, J. \& Fraiser, M.L., 2011. Trace fossil evidence for restoration of marine ecosystems following the end-Permian mass extinction in the Lower Yangtze region, South China. Palaeogeography, Palaeoclimatology, Palaeoecology 299, 449-474.

Chrząstek, A., 2008a. A new Lower Coniacian fauna from the Jerzmanice Zdrój region of the North Sudetic Basin, SW Poland. Geologia Sudetica 40, 33-50.

Chrząstek, A., 2008b. Vertebrate remains from the Lower Muschelkalk of Raciborowice Górne (North-Sudetic Basin, SW Poland). Geological Quarterly 52, 225-238.

Chrząstek, A., 2008c. Trace fossils from the Lower Muschelkalk of the North-Sudetic Basin (SW Poland). [In:] A. Uchman (Ed.): Abstract Book and the Intra-Congress Field Trip Guidebook. The Second International Congress on Ichnology (Cracow, Poland), p. 27.

Chrząstek, A. \& Wojewoda, J., 2011. Mesozoic of SouthWestern Poland (The North Sudetic Synclinorium). [In:] A. Żelaźniewicz (Ed.): Mezozoik i kenozoik Dolnego Śląska. 81 Zjazd PTG, Wrocław, 1-10.

Collignion, M., 1971-1972. Contribution à l'étude des basins sédimentaires. Le Bassin Cotier du Golfe du Menable (Madagascar). Caractère endémique de sa fauna. Bulletin de l'Academie Malgache 49, 153-162.

Cummings, J.P. \& Hodgson, D.M., 2011. Assessing controls on the distribution of ichnotaxa in submarine fan environments, the Basque Basin, northern Spain. Sedimentary Geology 239, 162-187.

D'Alessandro, A. \& Uchman, A., 2007. Bichordites and Bichordites-Rosselia ichnoassemblages from the Lower Pleistocene Tursi Sandstone (southern Italy). [In:] R.G. Bromley, L.A. Buatois, G. Mángano, J.F. Genise \& R.N. Melchor (Eds): Sediment-organism interactions: a multifaceted ichnology. SEPM Special Publication 88, 213-221.

Diedrich, C. \& Hirayama, R., 2003. Turtle remains (Testudines, Chelonioidea) from the Middle Turonian of northwest Germany. Netherlands Journal of Geosciences $82,161-167$.

Don, J., 1996. The Late Cretaceous Nysa Graben: implications for Mesozoic-Cenozoic fault-block tectonics of the Sudetes. Zeitschrift für Geologischen Wissenschaften 24, 317-324.

Don, B. \& Don, J., 1960. Notes on the origin of the Nysa Graben. Acta Geologica Polonica 10, 71-106. (In Polish, with English summary).

Don, J. \& Gotowała, R., 2008. Tectonic evolution of the late Cretaceous Nysa Kłodzka Graben, Sudetes, SW Poland. Geologia Sudetica 40, 51-63.

Don, J. \& Wojewoda, J., 2004. Tektonika rowu Górnej Nysy Kłodzkiej - sporne problemy [Tectonics of the upper Nysa Kłodzka Graben - controversial issues]. Przegląd Geologiczny 52, 883-886.

Don, J. \& Wojewoda, J., 2005. Tektonika rowu górnej Nysy Kłodzkiej - sporne problem - odpowiedź [Tectonics of upper Nysa Kłodzka Graben - controversial issues - reply). Przeglad Geologiczny 53, 212-221.

Ekrt, B., Košt'ák, M., Mazuch, M., Voigt, S. \& Wiese, F., 2008. New records of teleosts from the Late Turonian (Late Cretaceous) of the Bohemian Cretaceous Basin (Czech Republic). Cretaceous Research 29, 695-673.

Etter, W., 1996. Pseudoplanktonic and benthic invertebrates in the Middle Jurassic Opalinum Clay, northern Switzerland. Palaeogeography, Palaeoclimatology, Palaeoecology 126, 325-341.

Feldman, R.M., Schweitzer, C.E., Redman, C.M., Morris, N.J. \& Ward, D.J., 2007. New Late Cretaceous lobsters from the Kyzylkum Desert of Uzbekistan. Journal of Paleontology 81, 701-713.

Fistek, J. \& Gierwielaniec, J., 1957. Szczegótowa mapa geologiczna Sudetów w skali 1:25 000, arkusz Bystrzyca Nowa, M33-70Aa [Detailed geological map of the Sudetes, Bystrzyca Nowa sheet]. Wydawnictwa Geologiczne, Warszawa.

Fistek, J. \& Gierwielaniec, J., 1964. Objaśnienia do szczegótowej mapy geologicznej Sudetów, Arkusz Bystrzyca Nowa [Explanations to the detailed geological map of the Sudetes, Bystrzyca Nowa sheet]. Wydawnictwa Geologiczne, Warszawa, 5-63.

Flegel, K., 1904. Heuscheuer und Adersbach-Weckelsdorf. Eine Studie über die Obere Kreide im bohemisch-schlesischen Gebirge. Breslau, 36 pp.

Gale, A.S., 1996. Turonian correlation and sequence stratigraphy of the Chalk in southern England. [In:] S.P. Hesselbo \& D.N. Parkinson (Eds): Sequence stratigraphy in British geology. Geological Society Special Publications 103, 177-195. 
Gawor-Biedowa, E., 1980. Turonian and Coniacian foraminifera from the Nysa Trough, Sudetes, Poland. Acta Palaeontologica Polonica 25, 3-54.

Geinitz, H.B., 1840. Charakteristik der Schichten und Petrafecten des sächsischen Kreidegebirges. B. Fische, Crustaceen, Mollusken. Dresden/Leipzig, Arnoldischen Buchhandlung, 38-62.

Geinitz, H.B., 1842. Charakteristik der Schichten und Petrafecten des sächsisch-böhmischen Kreidegebirges. Die sächsisch-böhmische Schweiz, die Oberlausitz und das Innere von Böhmen. Dresden/Leipzig, Arnoldischen Buchhandlung, 63-116.

Geinitz, B.H., 1843. Die Versteinerungen von Kieslingswalda und Nachtrag zur Charakteristik des sächsisch-böhemischen Kreidegebirges. Dresden/Leipzig, Arnoldischen Buchhandlung, 1-23.

Giannetti, A., 2010. Influence of climate, sea-level changes and tectonics on ichnoassemblages distribution in a carbonate-dominated, deep-marine environment (Upper Paleocene, Zumaya section). Palaeogeography, Palaeoclimatology, Palaeoecology 285, 104-118.

Giannetti, A. \& McCann, T., 2010. The Upper Paleocene of the Zumaya Section (northern Spain): review of the ichnological content and preliminary palaeoecological interpretation. Ichnos 17, 137-161.

Gingras, M.K., MacEachern, J.A. \& Dashtgard, J.E., 2011. Process ichnology and the elucidation of physicchemical stress. Sedimentary Geology 237, 115-134.

Hancock, J.M., 1990. Sea-level changes in the British region during the Late Cretaceous. Proceedings of the Geologists' Association 100, 565-594.

Hancock, J.M. \& Kauffman, E.G., 1979. The great transgressions of the Late Cretaceous. Journal of the Geological Society of London 136, 175-186.

Hancock, J.M. \& Walaszczyk, I., 2004. Mid-Turonian to Coniacian changes of sea level around Dallas, Texas. Cretaceous Research 25, 459-471.

Haq, B., Hardenbol, J. \& Vail, P., 1987. Chronology of fluctuating sea levels since the Triassic. Science 235, 1156-1167.

Harries, P.J. \& Ozanne, C.R. 1998. General trends in predation and parasitism upon inoceramids. Acta Geologica Polonica 48, 377-386.

Herman, A.B. \& Spicer, R.A., 1997. New quantitative palaeoclimate data for the Late Cretaceous Arctic: evidence for a warm polar ocean. Palaeogeography, Palaeoclimatology, Palaeoecology 128, 227-251.

Hilbrecht, H. \& Harries, P.J., 1996. Lower Turonian Euramerican Inoceramidae. A morphologic, taxonomic, and biostratigraphic overview. [In:] P.J. Harries, E.G. Kauffman and J.S. Crampton (Eds): A report from the First Workshop on Early Turonian Inoceramids (Hamburg). Mitteilungen aus dem GeologischPaläontologischen Museum der Universität Hamburg 77, 641-671.

Hofmann, R., Goudemand, N., Wasmer, M., Bucher, H. \& Hautmann, M., 2011. New trace fossil evidence for an early recovery signal in the aftermath of the endPermian mass extinction. Palaeogeography, Palaeoclimatology, Palaeoecology 310, 216-226.
Ion, J., Antonescu, E., Melinite, M.C. \& Szasz, L., 2004. Integrated biostratigraphy of the Turonian of Romania. Acta Palaeontologica Romaniae 4, 151-161.

Ivannikov, A.V., 1967. A giant ammonite from the southern border of the Donets Basin, USSR. Dopovidi Akademiyi Nauk Ukrayins'koyi RSR, seriya B: Geologiya, Geofizika, Khimiya ta Biologiya 1, 13-17.

Jagt-Yazykova, E.A., 2011. Palaeobiogeographical and palaeobiological aspects of mid- and Late Cretaceous ammonite evolution and bio-events in the Russian Pacific. Scripta Geologica 143, 15-121.

Jagt-Yazykova, E.A. (in press). Ammonite faunal dynamics across bio-events during the mid- and Late Cretaceous along the Russian Pacific coast. Acta Palaeontologica Polonica (http://dx.doi.org/10.4202/ app.2011.0076).

Jerzykiewicz, T., 1970. The Upper Cretaceous turbidite sequence in the Sudetes (south-western Poland). Bulletin de l'Académie Polonaise des Sciences, Série des Sciences Géologiques et Géographiques 18, 149-159.

Jerzykiewicz, T., 1971. A flysch/littoral succession in the Sudetic Upper Cretaceous. Acta Geologica Polonica 21, 165-199.

Jerzykiewicz, T., 1975. Pozycja geologiczna osadów górno kredowych depresji śródsudeckiej i rowu Nysy Kłodzkiej [Tectonic position of the Late Cretaceous deposits in the Intra-Sudetic Basin and the Nysa Kłodzka Graben]. [In:] A. Grocholski (Ed.): Przewodnik 48 Zjazdu PTG. 30 lat geologii polskiej na Dolnym Śląsku (Świdnica), 225-252.

Jerzykiewicz, T. \& Teisseyre, B., 1974. Foraminiferal assemblages and facies changes in the Cretaceous flysch of the Nysa Graben (Sudety Mountains). Annales Societatis Geologorum Poloniae 46, 203-216.

Kaesler, R.L., 1996. Treatise on invertebrate paleontology. Part L. Mollusca 4. Revisited. Volume 4: Cretaceous Ammonoidea. The Geological Society of America / University of Kansas, 362 pp.

Kaplan, U. \& Kennedy, W.J., 1996. Upper Turonian and Coniacian ammonite stratigraphy of Westphalia, NWGermany. Acta Geologica Polonica 46, 305-352.

Kauffman, E.G., Harries, P.J., Meyer, C., Villamil, T., Arango, C. \& Jaecks, G., 2007. Paleoecology of giant Inoceramidae (Platyceramus) on a Santonian (Cretaceous) seafloor in Colorado. Journal of Paleontology 81, 64-81.

Kennedy, W.J. \& Wright, C.W., 1979. Vascoceratid ammonites from the type Turonian. Palaeontology 22, 665-683.

Kennedy, W.J. \& Wright, C.W., 1981. Desmoceratacean ammonites from the type Turonian. Palaeontology 24, 493-506.

Kennedy, W.J., Wright, C.W. \& Chancellor, G.R., 1983. The Cretaceous ammonite Eopachydiscus and the origin of the Pachydiscidae. Paleontology 26, 655-662.

Kennedy, W.J., Cobban, W.A., Hancock, J.M. \& Gale, A.S., 2005a. Upper Albian and Lower Cenomanian ammonites from the Main Street Limestone, Graylon Marl and Del Rio Clay in northeast Texas. Cretaceous Research 26, 349-428. 
Kennedy, W.J., Walaszczyk, I. \& Cobban, W.A., 2005b. The Global Boundary Section and Point for the base of the Turonian stage of the Cretaceous: Pueblo, Colorado, U.S.A. Episodes 28, 93-104.

Kędzierski, M., 2005. Paleogeografia wschodniej części basenu wokółsudeckiego w cenomanie, turonie i koniaku [Palaeogeography of the estern part of the Circum-Sudetic Basin in the Cenomanian, Turonian and Coniacian]. [In:] J. Skoczylas (Ed.): Referaty XIV. Polskie Towarzystwo Geologiczne, Uniwersytet Adama Mickiewicza, Poznań, 49-58.

Kędzierski, M., 2008. Calcareous nannofossil and inoceramid biostratigraphies of a Middle Turonian to Middle Coniacian section from the Opole Trough of SW Poland. Cretaceous Research 29, 451-467.

Kędzierski, M. \& Uchman, A., 2001. Ichnofabric of the Upper Cretaceous marlstones in the Opole region, southern Poland. Acta Geologica Polonica 51, 81-91.

Kędzierski, M., Machaniec, E., Rodríguez-Tovar, F.J. \& Uchman, A., 2012. Bio-events, foraminiferal and nannofossil biostratigraphy of the Cenomanian/Turonian boundary interval in the Subsilesian Nappe, Rybie section, Polish Carpathians. Cretaceous Research 35, 181-198.

Kin, A., 2007. Uwagi o rodzaju Lewesiceras (Pachydiscidae) ze środkowego i górnego turonu kamieniołomu Odra Nowa w Opolu [Some remarks concerning the genus Lewesiceras (Pachydiscidae) from the Middle and Upper Turonian of the Odra Nowa quarry in Opole]. [In:] A. Żylińska (Ed.): Granice paleontologii. XX Konferencja Naukowa Paleobiologów i Biostratygrafów PTG, Uniwersytet Warszawski, p. 67.

Kin, A. \& Niedźwiedzki, R., 2012. First record of the puzosiine ammonite genus Pachydesmoceras from the Middle and Upper Turonian of Poland. Cretaceous Research 33, 15-20.

Klug, Ch., 2002. Conch parameters and habitats of Emsian and Eifelian ammonoids from the Tafilalt (Morocco) and their relation to global events. Abhandlungen der geologischen Bundesanstalt 57, 523-538.

Knaust, D., 2009. Characterisation of a Campanian deepsea fan system in the Norwegian Sea by means of ichnofabrics. Marine and Petroleum Geology 26, 11991211.

Komuda, J. \& Don, J., 1964. On the brachyanticline in Bystrzyca Kłodzka (Sudeten Mts., Poland). Acta Geologica Polonica 14, 169-174 (In Polish with English summary).

Košt'ák, M. \& Wiese, F., 2011. Extremely rare Turonian belemnites from the Bohemian Cretaceous Basin and their palaeogeographical importance. Acta Palaeontologica Polonica 56, 433-437.

Košt'ák, M., Čech, S., Ekrt, B., Mazuch, M., Wiese, F., Voigt, S. \& Wood, Ch.J., 2004. Belemnites of the Bohemian Cretaceous Basin in a global context. Acta Geologica Polonica,54, 511-533.

Kumagae, T., Maeda, H. \& Komatsu, T., 2011. Paleoecology of Inoceramus amakusensis Nagao et Matsumoto, 1940 (Bivalvia) in a Late Cretaceous shallow clastic sea: the Himenoura Group, Kyushu, Japan. Cretaceous Research 32, 738-749.
Lamolda, M.A., López, G. \& Martínez, R., 1989. Turonian integrated biostratigraphy in the Estella Basin (Navarra, Spain). [In:] J. Wiedman (Ed.): Cretaceous of the Western Tethys, Proceedings of the 3rd International Cretaceous Symposium (Tübingen). Stuttgart-Schweizerbart, 145-159.

Landman, N.H., Cobban, W.A. \& Larson, N.L. 2012. Mode of life and habitat of scaphitid ammonites. Geobios, 45, 87-98.

Lommerzheim, A., 1976. Zur Paläontologie, Fazies, Palaeogeographie und Stratigraphie der turonen Grünsande (Oberkreide) im Raum Mülheim/Broich/ Speldorf (Westfalen) mit einer Beschreibung der Cephalopodenfauna [Paleontology, facies, paleogeography and stratigraphy of Turonian greensands (Upper Cretaceous) in the Mulheim-Broich-Speldorf region (Westphalia) with a description of the Cephalopod fauna]. Decheniana 129, 197-244. (in German, with English summary)

Lorenc, S., 1978. Petrografia skat osadowych [Petrography of sedimentary rocks]. Wydawnictwa Uniwersytetu Wrocławskiego, 176 pp.

MacEachern, J.A. \& Gingras, M.K., 2007. Recognition of brackish-water trace-fossil suites in the Cretaceous Western Interior Seaway of Alberta Canada. [In:] R.G. Bromley, L.A. Buatois, G. Mángano, J.F. Genise \& R.N. Melchor (Eds): Sediment-organism interactions: a multifaceted ichnology. SEPM Special Publication 88, 149-193.

MacEachern, J.A., Pemberton, S.G., Gingras, M.K. \& Bann, K.L., 2007. The ichnofacies paradigm: a fiftyyear retrospective. [In:] W. Miller, III (Ed.): Trace fossils - concepts, -problems, prospects. Elsevier, Amsterdam, 51-77.

Machalski, M., 2012. Stratigraphically important ammonites from the Campanian-Maastrichtian boundary interval of the Middle Vistula River section, central Poland. Acta Geologica Polonica 62, 91-116.

Malinowska, L., 1984. Budowa geologiczna Polski, Tom II, Atlas skamieniatości przewodnich i charakterystycznych, część 2c, Mezozoik, Kreda [Geology of Poland, Part II, Atlas of fossils, 2c, Mesozoic, Cretaceous]. Wydawnictwa Geologiczne, Warszawa, 579 pp.

Malpas, J.A., Gawthorpe, R.L., Pollard, J.E. \& Sharp, I.R., 2005. Ichnofabric analysis of the shallow marine Nukhul Formation (Miocene), Suez Rift, Egypt: implications for depositional processes and sequence stratigraphic evolution. Palaeogeography, Palaeoclimatology, Palaeoecology 215, 239-264.

Manecki, A. \& Muszyński, M., 2008. Przewodnik do petrografii [A guide to petrography]. AGH, Kraków, 551 pp.

Marcinowski, R., 1974. The transgressive Cretaceous (Upper Albian through Turonian) deposits of the Polish Jura chain. Acta Geologica Polonica 24, 117-217.

Marcinowski, R. \& Szulczewski, M., 1972. Condensed Cretaceous sequence with stromatolites in the Polish Jura chain. Acta Geologica Polonica 22, 515-538.

Marcinowski, R., Walaszczyk, I. \& Olszewska-Nejbert, D., 1996. Stratigraphy and regional development of the mid-Cretaceous (Upper Albian through Coniacian) 
of the Mangyshlak Mountains, Western Kazakhstan. Acta Geologica Polonica 46, 1-60.

Martin, K.-D., 2004. A re-evaluation of the relationship between trace fossils and dysoxia. [In:] D. Mcllroy (Ed.): The application of ichnology to palaeoenvironmental and stratigraphic analysis. Geological Society, London, Special Publications 228, 141-156.

Matsukawa, M., Sendon, S.V., Mateer, F.T, Sato, T. \& Obata, I., 2012. Early Cretaceous ammonite fauna of Catanduanes Island, Philippines. Cretaceous Research 37, 261-271.

Matsumoto, T., 1979. Notes on Lewesiceras and Nowakites (pachydiscid ammonites) from the Cretaceous of Hokkaido. Transaction and Proceedings of the Palaeontological Society of Japan. New Series II, 30-44.

Matsumoto, T., 2003. A pachydiscid ammonite Lewesiceras from the Cenomanian of Japan. Studies of the Cretaceous ammonites from Hokkaido and Sakhalin-XCVI. Proceedings of the Japan Academy, Series B: Physical and Biological Sciences 79, 197-200.

Matsumoto, T., Nemoto, M. \& Suzuki, Ch., 1990. Gigantic ammonites from the Cretaceous Futaba Group of Fukushima Prefecture. Transaction and Proceedings of the Palaeontological Society of Japan 157, 366-381.

McCann, T., 1990. Distribution of Ordovician-Silurian ichnofossil assemblages in Wales - implications for Phanerozoic ichnofaunas. Lethaia 23, 243-255.

McIlroy, D., 2007. Ichnology of a macrotidal tide-dominated deltaic depositional system: Lajas Formation, Neuquén Province, Argentina. [In:] R.G. Bromley, L.A. Buatois, G. Mángano, J.F. Genise \& R.N. Melchor (Eds): Sediment-organisms interactions: a multifaceted ichnology. SEPM Special Publication 88, 195-211.

Mitura, F., 1957. Inoceramy górnokredowe Bachowic [Inocérames du Crétacé supérieur de Bachowice]. Annales Societatis Geologorum Poloniae 26, 273-296. (in Polish, with French and Russian summaries)

Monaco, P., Rodríguez-Tovar, F.J. \& Uchman, A., 2012. Ichnological analysis of lateral environmental heterogeneity within the Bonarelli Level (uppermost Cenomanian) in the classical localities near Gubbio, central Appenines, Italy. Palaios 27, 48-54.

Monnet, C. \& Bücher, H., 2007. Ammonite-based correlations in the Cenomanian-Lower Turonian of northwest Europe, central Tunisia and the Western Interior (North America). Cretaceous Research 28, 1017-1032.

Moore, R.C., 1964. Treatise on invertebrate paleontology, Part C, Protista 2, Sarcodina, Chiefly "Thecomoebians" and Foraminiferida, Vol. 1-2. Geological Society of America / University of Kansas Press, Kansas, 900 pp.

Moore, R.C., 1968. Treatise on invertebrate paleontology, Part L, Mollusca 4, Cephalopoda, Ammonoidea. Geological Society of America / University of Kansas Press, Kansas, 490 pp.

Mortimore, R.N. \& Pomerol, B., 1991. Stratigraphy and eustatic implications of trace fossil events in the Upper Cretaceous chalk of northern Europe. Palaios 5, 216-231.

Niedźwiedzki, R. \& Kalina, M., 2003. Late Cretaceous sharks in the Opole Silesia region (SW Poland). Geologia Sudetica 35, 13-24.
Niedźwiedzki, R. \& Salamon, M., 2005. Late Cretaceous crinoids from the Sudetes (southern Poland). Freiberger Forschungshefte C 507: Paläontologie, Stratigraphie. Fazies 13, 1-9.

Olivero, E.B., 2012. Sedimentary cycles, ammonite diversity and palaeoenvironmental changes in the Upper Cretaceous Marambio Group, Antarctica. Cretaceous Research 34, 348-366.

Ozanne, C.R. \& Harries, P.J., 2002. Role of predation and parasitism in the extinction of the inoceramid bivalves: an evaluation. Lethaia 35, 1-19.

Pachucki, C., 1959. O stratygrafii i litologii kredy w rowie Nysy Kłodzkiej [Über die Stratigraphie und Lithologie der Kreide in Neissegraben]. Annales Universitatis M. Curie-Skłodowskiej 12, 1-65. (in Polish, with summaries in Russian and German]

Phillips, Ch., McIlroy, D. \& Elliott, T. 2011. Ichnological characterization of Eocene/Oligocene turbidites from the Grès d'Annet Basin, French Alps, SE France. Palaeogeography, Palaeoclimatology, Palaeoecology 300, 67-83.

Radwańska, Z., 1962. Fauna spągowych warstw strefy Inoceramus schloenbachi z Wilkanowa (Dolny Śląsk) [The fauna of the bottom beds of Inoceramus schloenbachi Zone from Wilkanów (Lower Silesia)]. Biuletyn Państwowego Instytutu Geologicznego 173, 129-167. (in Polish, with English summary)

Radwańska, Z., 1964. Górnoturońska strefa Inoceramus glatziae w niecce śródsudeckiej i w rowie Nysy [The Upper Turonian Inoceramus glatziae Zone in the Intra-Sudetic Basin and in the Nysa Kłodzka Graben]. Przeglad Geologiczny 7/8, 336-338.

Radwański, S., 1964. Niektóre dane o kredzie na Dolnym Śląsku [Some data on the Cretaceous in Lower Silesia]. Przeglad Geologiczny 7/8, 333-336.

Radwański, S., 1965. Budowa geologiczna rowu Nysy w okolicach Bystrzycy Kłodzkiej i Długopola Dolnego [Geology of the Nysa Graben in the vicinity of Bystrzyca Kłodzka and Długopole Dolne]. Biuletyn Instytutu Geologicznego 185, 229-242. (in Polish, with English summary).

Radwański, S., 1966. Facje osadowe i charakterystyka faunistyczna górnej kredy Środkowych Sudetów [Upper Cretaceous facies and faunas in the central part of the Sudety Mts]. Rocznik PTG 36, 99-119. (in Polish, with English summary).

Radwański, S., 1968. Górnokredowe osady w Sudetach i wpływ tektoniki na ich sedymentacje [Upper Cretaceous deposits in Sudetes and influence of tectonics upon their sedimentation]. Kwartalnik Geologiczny 12, 607-619. (in Polish, with English summary)

Radwański, S., 1975. Kreda Sudetów Srodkowych w świetle wyników nowych otworów wiertniczych [Upper Cretaceous of the central part of the Sudetes in the light of new borehole materials]. Biuletyn Instytutu Geologicznego 287, 5-59. (in Polish, with English summary)

Remin, Z., 2010. Upper Coniacian, Santonian, and lowermost Campanian ammonites of the Lipnik-Kije section, central Poland - taxonomy, stratigraphy, and 
palaeogeographic significance. Cretaceous Research 31, 154-180.

Robaszyński, F., Pomerol, B., Masure, E., Bellier, J.-P. \& Deconinck, J.-F., 2005. Stratigraphy and stage boundaries in reference sections of the Upper Cretaceous Chalk in the east of the Paris Basin: the "Craie 700" Provins boreholes. Cretaceous Research 26, 157-169.

Rodríguez-Tovar, F.J. \& Uchman, A., 2010. Ichnofabric evidence for the lack of bottom anoxia during the Lower Toarcian Oceanic Anoxic Event in the Fuente de la Vidriera section, Bethic Cordillera, Spain. Palaios 25, 576-587.

Rodríguez-Tovar, F.J., Uchman, A., Martin-Algarra, A. \& O'Dogherty, L., 2009. Nutrient spatial variation during intrabasinal upwelling at the Cenomanian-Turonic oceanic anoxic event in the westernmost Tethys: an ichnological and facies approach. Sedimentary Geology 215, 83-93.

Rotnicka, J., 2005. Ichnofabrics of the Upper Cretaceous fine-grained rocks from the Góry Stołowe Mountains (Sudetes, SW Poland). Geological Quarterly 49, 15-30.

Rotnicka, J., 2007. Transgressive and regressive cycles in fine-grained rocks successions: an example from the Upper Cretaceous Plänermergel, Góry Stołowe Mts., Sudetes. [In:] J. Wojewoda (Ed.): Review of Permian sedimentary successions of Boskovice Trough, Nachod Basin and Trutnov Basin. Sedimentologica 1, 18-30.

Savary, B., Olivero, D. \& Gaillard, C., 2004. Calciturbidite dynamics and endobenthic colonization: example from a late Barremian (Early Cretaceous) succession in southeastern France. Palaeogeography, Palaeoclimatology, Palaeoecology 211, 221-239.

Savrda, C.E., 1995. Ichnologic applications in paleoceanographic, paleoclimatic, and sea-level studies. Palaios 10, 565-577.

Savrda, C.E., 2007. Trace fossils and marine benthic oxygenation. [In:] W. Miller, III (Ed.): Trace fossils - concepts, problems, prospects. Elsevier, Amsterdam, 149158.

Savrda, C.E. \& Bottjer, D.J., 1986. Trace fossil model for reconstruction of paleo-oxygenation in bottom waters. Geology 14, 3-6.

Schoeneichowa-Jaskowiak, M. \& Krassowska, A., 1988. Paleomiąższości, litofacje i paleotektonika epikontynentalnej kredy górnej w Polsce [Palaeothickness, lithofacies and palaeotectonics of the epicontinental Upper Cretaceous in Poland]. Kwartalnik Geologiczny 32, 177-198. (in Polish, with English summary)

Scupin, H., 1907. Die stratigraphische Beziehungen der obersten Kreideschichten in Sachsen, Schlesien und Böhmen. Neues Jahrbuch für Mineralogie, Geologie und Paläontologie 24, 676-715.

Scupin, H., 1912-1913. Die Löwenberger Kreide und ihre Fauna. Palaeontographische Beiträge zur Naturgeschichte der Vorzeit, Supplement Band 6, 5-275.

Scupin, H., 1935. Die stratigraphische Beziehungen der mittel-und nordsudetischen Kreide. Zeitschrift der deutschen geologischen Gesellschaft 87, 523-540.
Scupin, H., 1936. Zur Paläogeographie des Sudetischen Kreidemeeres. Zeitschrift der deutschen geologische Gesellschaft 88, 309-325.

Seibertz, E., 1978. Ökologie, Fazies und Fauna im Turon des südlichen Münsterlandes: ein Fazies Wirkungsschema. Pälaontologische Zeitschrift 52, 93-109.

Seilacher, A., 1967. Bathymetry of trace fossils. Marine Geology 5, 413-428.

Sornay, J. 1964. Sur un Lewesiceras nouveau du Turonien d'Uchaux (Vaucluse). Annales de Paléontologiey, Invertébrates 50, 181-187.

Stevens, G.R., 1988. Giant ammonites: a review. [In:] J. Wiedman \& J. Kullmann (Eds): $2^{\text {nd }}$ International Cephalopod Symposium 'Cephalopods - Present and Past' (O.H. Schindewolf Symposium, Tübingen). E. Schweizerbart'sche Verlagsbuchhandlung, Stuttgart, 141-166.

Summesberger, H., Švábenicka, L., Čech, S., Hradecká, L. \& Hofmann, T., 1999. New palaeontological and biostratigraphical data on the Klement and Pálava Formations (Upper Cretaceous) in Austria (Waschberg-Ždánice Unit). Geologie und Paläontologie, Naturhistorisches Museum Wien 100 A, 39-79.

Stürm, F., 1901. Der Sandstein von Kieslingswalde in der Grafschaft Glatz und seine Fauna. Jahrbuch der Königlichen preussischen geologischen Landesanstalt und Bergakademie, Abhandlungen von ausserhalb der Königlichen geologischen Landesanstalt stehenden Personen 21, 39-98.

Szulc, J., 1990. Ichnological indicators of the sedimentary environment fluctuation. [In:] A. Bodzioch, S. Kwiatkowski, M. Michalik, E. Morycowa \& J. Szulc (Eds): International Workshop - Field Seminar 'The Muschelkalk - sedimentary environments, facies and diagenesis' (Kraków), 23-25.

Szulc, J., 2000. Middle Triassic evolution of the northern Peri-Tethys area as influenced by early opening of the Tethys Ocean. Annales Societatis Geologorum Poloniae $70,1-48$.

Tarkowski, R., 1991. Stratygrafia, makroskamieniałości i paleogeografia utworów górnej kredy niecki opolskiej [Stratigraphy, macrofossils and palaeogeography of the Upper Cretaceous from the Opole Trough]. Zeszyty Naukowe AGH, Geologia 51, 1-156. (in Polish, with English summary)

Teisseyre, B., 1975. Stratygrafia mikrofaunistyczna górnej kredy rowu Nysy (Sudety środkowe) [Stratigraphy based upon Foraminifera of Upper Cretaceous deposits, Nysa Graben, Central Sudetes]. Rocznik PTG 45, 81-136. (in Polish, with English summary)

Teisseyre, B., 1992. Otwornice kredy górnej z niecki północnosudeckiej (Sudety Zachodnie) [Upper Cretaceous foraminifers from the North Sudetic Basin (Western Sudetes)]. Acta Universitatis Wratislaviensis, Prace Geologiczno-Mineralogiczne 34, 1-78. (in Polish, with English summary)

Tibuleac, P. 2008. Presence of big size ammonites in the Jurassic olistoliths of Transylvanian Nappe(s) from Rasău Syncline (eastern Carpathians, Romania). Acta Palaeontologica Romaniae 6, 365-374. 
Trbušek, J., 1999. Upper Cretaceous sharks and rays from the Prokop opencast mine at Březina near Moravská Třebová. Acta Universitatis Palackianae Olomucensis Facultas Rerum Naturalium, Geologica 36, 51-61.

Trussell, G.C. \& Smith, L.D., 2000. Induced defenses in response to an invading crab predator: an explanation of historical and geographic phenotypic change. Proceedings of the National Academy of Sciences 97, 2123-2127.

Tsujita, C.T. \& Westermann, G.E.G., 1998. Ammonoid habitats and habits in the Western Interior Seaway: a case study from the Upper Cretaceous Bearpaw Formation of southern Alberta, Canada. Palaeogeography, Palaeoclimatology, Palaeoecology 144, 135-160.

Twitchett, R. J. \& Wignall, P.B., 1996. Trace fossils and the aftermath of the Permo-Triassic mass extinction: evidence from northern Italy. Palaeogeography, Palaeoclimatology, Palaeoecology 124, 137-151.

Uchman, A., Bąk, K. \& Rodríguez-Tovar, F.J., 2008. Ichnological record of deep-sea palaeoenvironmental changes around the Oceanic Anoxic Event 2 (Cenomanian-Turonian boundary): an example from the Barnasiówka section, Polish Outer Carpathians. Palaeogeography, Palaeoclimatology, Palaeoecology 262, 61-71.

Uličný, D., 2001. Depositional systems and sequence stratigraphy of coarse-grained deltas in a shallow-marine, strike-slip setting: the Bohemian Cretaceous Basin, Czech Republic. Sedimentology 48, 599-628.

Uličný, D., Hladíková, J., Attrep Jr., M.S., Čech, S., Hradecká, L. \& Svobodová, M., 1997. Sea-level changes and geochemical anomalies across the Cenomanian-Turonian boundary: Pecínov quarry, Bohemia. Palaeogeography, Palaeoclimatology, Palaeoecology 132, 265-285.

Vodrážka, R., Sklenář, J., Čech, S., Laurin, J. \& Hradecká, L. 2009. Phosphatic intraclasts in shallow-water hemipelagic strata: a source of palaeoecological, taphonomic and biostratigraphic data (Upper Turonian, Bohemian Cretaceous Basin). Cretaceous Research 30, 204-222.

Walaszczyk, I., 1988. Inoceramid stratigraphy of the Turonian and Coniacian strata in the environs of Opole (Southern Poland). Acta Geologica Polonica 38, 51-61.

Walaszczyk, I., 1992. Turonian through Santonian deposits of the central Polish uplands; their facies development, inoceramid paleontology and stratigraphy. Acta Geologica Polonica 42, 1-122.

Walaszczyk, I. \& Wood, Ch.J., 1998. Inoceramids and biostratigraphy at the Turonian/Coniacian boundary; based on the Salzgitter-Salder Quarry, Lower Saxony, Germany, and the Słupia Nadbrzeżna section, central Poland. Acta Geologica Polonica 48, 395-434.

Walaszczyk, I., Kopaevich, L.F. \& Olferiev, G., 2004a. Inoceramid/foraminiferal succession of the Turonian and Coniacian (Upper Cretaceous) of the Briansk region (central European Russia). Acta Geologica Polonica 54, 597-609.

Walaszczyk, I., Marcinowski, R., Praszkier, T., Dembicz, K. \& Bieńkowska, M., 2004b. Biogeographical and stratigraphical significance of the latest Turonian and Early Coniacian inoceramid/ammonite succession of the Manasoa section on the Onilahy River, south-west Madagascar. Cretaceous Research 25, 543-576.

Wetzel, A. \& Reisdorf, A.G., 2007. Ichnofabrics elucidate the accumulation history of a condensed interval containing a vertically emplaced ichthyosaur skull. [In:] G. Bromley, L.A. Buatois, G. Mángano, J.F. Genise \& R.N. Melchor (Eds): Sediment-organism interactions: a multifaceted ichnology. SEPM Special Publications 88, 241-251.

Wetzel, A. \& Uchman, A., 2001. Sequential colonization of muddy turbidites in the Eocene Beloveža Formation, Carpathians, Poland. Palaeogeography, Palaeoclimatology, Palaeoecology 168, 171-186.

Wetzel, A., Tjallingii, R. \& Wiesner, M.G., 2011. Bioturbational structures record environmental changes in the upwelling area off Vietnam (South China Sea) for the last 150,000 years. Palaeogeography, Palaeoclimatology, Palaeoecology 311, 256-267.

Wiedman, D., 1989. Fossilien aus dem Turon des Teutoburger Waldes aus der Sammlung Dietrich Wiedmann, Hannover. Zeitschrift für Amateur-Paläontologen (Arbeitskreis Pälaontologie Hannover) 6, 141-147.

Wiese, F. \& Kaplan, U., 2001. The potential of the Lengerich section (Münster Basin, northern Germany) as a possible candidate Global Boundary Stratotype Section and Point (GSSP) for the Middle/Upper Turonian boundary. Cretaceous Research 22, 549-563.

Wiese, F. \& Voigt, S., 2002. Late Turonian (Cretaceous) climate cooling in Europe: faunal response and possible causes. Geobios 35, 65-77.

Wiese, F., Čech, S., Ekrt, B., Košt'ák, M., Mazuch, M. \& Voigt, S., 2004. The Upper Turonian of the Bohemian Cretaceous Basin (Czech Republic) exemplified by the Úpohlavy working quarry: integrated stratigraphy and palaeoceanography of a gateway to the Tethys. Cretaceous Research 25, 329-352.

Witwicka, E., 1958. Micropalaeontological stratigraphy of Upper Cretaceous of the Chełm Borehole (Lublin Upland). Biuletyn Instytutu Geologicznego 121, 177-267.

Wojewoda, J., 1997. Upper Cretaceous litoral-to-shelf succession in the Intrasudetic Basin and Nysa Trough, Sudety Mountains. [In:] J. Wojewoda (Ed.): Obszary źródtowe: Zapis w osadach. WIND, Wrocław, 81-96.

Wojewoda, J., 2004. Skamieniałości śladowe w płytkowodnych osadach santonu na obszarze rowu Górnej Nysy Kłodzkiej [Trace fossils in the shallow deposits of the Upper Nysa Kłodzka Graben]. [In:] J. Muszer (Ed): Zapis paleontologiczny jako wskaźnik paleośrodowisk (Wrocław), 95-96.

Woods, M.A., 2007. Chalk Group macrofossils from the Basingstoke (Sheet 284) and Aldershot (Sheet 285) districts. British Geological Survey, Geology E Landscape, Southern Britain Programme, Open Raport OR/07/07, 1-18.

Wroński, J., 1981. Szczegótowa mapa geologiczna Sudetów w skali 1: 25 000, arkusz Bystrzyca Kłodzka [Detailed geological map of the Sudety Mountains, Bystrzyca Kłodzka sheet]. Wydawnictwa Geologiczne, Warszawa.

Wroński, J. \& Cwojdziński, S., 1984. Objaśnienia do szczegótowej mapy geologicznej Sudetów, Arkusz Bystrzyca 
Kłodzka [Explanations to the geological map of the Sudetes, Bystrzyca Kłodzka sheet]. Wydawnictwa Geologiczne, Warszawa, 5-67.

Yacobucci, M.M., 2004. Neogastroplites meets Metengonoceras: morphological response of an endemic hoplitid ammonite to a new invader in the mid-Cretaceous Mowry Sea of North America. Cretaceous Research 25, 927-944.

Zakharov, Y.D., Melnikov, M.E., Popov, A.M., Pletnev, S.P., Khudik, V.D. \& Punina, T.A., 2012. Cephalopod and brachiopod fossils from the Pacific: evidence from the Upper Cretaceous of the Magellan Seamounts. Geobios 45, 145-156.

Żelaźniewicz, A. \& Aleksandrowski, P., 2008. Regionalizacja tektoniczna Polski - Polska południowo-zachodnia [Tectonic subdivision of Poland: southwestern
Poland]. Przeglad Geologiczny 56, 904-911. (in Polish, with English summary)

Zonova, T.D. \& Yazykowa, E.A., 1998. Biostratigraphy and correlation of the Turonian-Coniacian boundary problem in the Far East Russia based on ammonites and inoceramids. Acta Geologica Polonica 48, 483-494.

Zonneveld, J.-P., Gingras, M.-K. \& Beatty, T.-W., 2010. Diverse ichnofossil assemblages following the P-T mass extinction, Lower Triassic, Alberta and British Columbia, Canada: evidence for shallow marine refugia on the northwestern coast of Pangea. Palaios 25, 368-392.

Manuscript received: 12 April 2012 Revision accepted: 22 June 2012 